\title{
Tax Planning atas Pajak Penghasilan Badan
}

\author{
Dheo Rimbano \\ STIE Musi Rawas (MURA) \\ Lubuklinggau, Indonesia \\ rimbanodheo@gmail.com
}

\author{
Mirra Sri Wahyuni \\ STIE Musi Rawas (MURA) \\ Lubuklinggau, Indonesia \\ mirrasriwahyuni91@gmail.com
}

\author{
Eri Triharyati \\ STIE Musi Rawas (MURA) \\ Lubuklinggau, Indonesia \\ 3triharyati@gmail.com
}

\begin{abstract}
ABSTRAK
Corporate income tax is a mandatory thing to pay. awareness of paying is still minimal, Islam is more familiar with the term 'zakat' than tax (Awareness in paying zakat is very high for Muslims), raising awareness begins with the planning process, so the obstacles in every plan to pay taxes need to be known. The possibility of taxpayers already knowing their obligations, but the meaning is like "double-edged knife", the existence of a trend positivein paying taxes is still to be studied, whether based on the tax amnesty and / or tax planning that starts to run, the negative side of tax amnesty is the fact that Our taxes are categorized as "stubborn" in their discipline of paying taxes. With the existence of tax planning, the taxpayer can save tax that actually exceeds its obligations, and on the other hand help taxpayers in making decisions relating to investment plans in the future. Given the limitations of researchers both in terms of theoretical and technical matters, so that the discussion is clearer, directed and this research does not deviate from the existing problems, the research focus is on the scope of Tax Planning with Law No. 36 of 2008 concerning Income Tax and Tax Regulations other companies in all Commander Companies (CV) in Lubuklinggau City and Bengkulu City. by using qualitative analysis, to analyze tax planning (tax planning) for corporate income tax. then consider the actions that should be taken in streamlining the 2015 owed Corporate Income Tax under Law No. 36 of 2008 article 9 paragraph (1) and Law No. 36 of 2008 article 9 paragraph (1) letter e, activities can be carried out as follows: (1) Provision of health benefits for employees; (2) Providing HR development and education for employees; (3) Provision of bonuses for employee performance; (4) Provision of vehicles for transportation; and (5) giving uniforms to employees. The results of the study show that (1) the Tax Planning of the PPH of the Agency in accordance with the Tax Regulations the majority of the CVs are not yet implemented and (2) In the financial management of CVs both in Lubuklinggau City and Bengkulu City have not been able to make efficient PPH payments.
\end{abstract}

Keywords: Tax Planning, PPH Agency (CV)

Pendahuluan

Perencanaan dapat dikatakan sebagai dasar dalam sebuah manajemen (pengelolaan), umumnya ketika sebuah Perusahaan melakukan sebuah perencanaan, maka Perusahaan itu kembali menghidukan seni dalam mencapai tujuan sebuah organisasi, tentunya seni tersebut diikuti dengan langkah langkah strategi yang jelas, sehingga dari strategi tersebut akan muncul teknis cara yang lebih spesifik dalam mencapai tujuan agar terealisasi. Umumnya semua Perusahaan Komanditer pasti memiliki tujuan utama, yakni menghasilkan keuntungan yang masif, baik dalam waktu dengan jangka yang pebdek dan waktu dengan jangka yang panjang, tetapi proses untuk mendapatkan keuntungan tersebut harus kita ikuti dengan mengikuti aturan yang resmi, seperti perundang undangan pajak.

Biasanyan pemilik perusahaan akan membuat sebuah rekayasa proses transaksi agar mereka menghasilkan laporan, sehingga dari penilaian tentang perpajakan atas laporan tersebut tidak membebankan mereka membayar pajak yang tinggi, Namun, perencanaan pajak juga dapat bersifat positif sebagai perencanaan pemenuhan kewajiban perpajakan secara lengkap, benar, dan tepat waktu sehingga dapat menghindari pemborosan sumber daya. 
Tabel 1 : Perkembangan Penerimaan Pajak, Tahun 2011 - 2015

\begin{tabular}{|c|c|c|c|}
\hline Tahun & $\begin{array}{c}\text { Jumlah } \\
(\mathbf{R p )}\end{array}$ & $\begin{array}{c}\text { Kenaikan } \\
\text { (Index) }\end{array}$ & $\begin{array}{c}\text { Selisih } \\
\text { (Presentase) }\end{array}$ \\
\hline 2010 & 649,0 & - & - \\
\hline 2011 & 837,9 & 188,8 & $20,8 \%$ \\
\hline 2012 & 980,5 & 142,6 & $12,2 \%$ \\
\hline 2013 & $1.077,3$ & 96,8 & $9,9 \%$ \\
\hline 2014 & $1.146,5$ & 69,2 & $6,4 \%$ \\
\hline 2015 & $1.489,3$ & 342,8 & $29,9 \%$ \\
\hline
\end{tabular}

Data di atas dapat menjadi salah satu dasar pemikiran kita bahwa wajib pajak sudah mulai mengetahui akan kewajibannya, namun makna dari data tersebut seperti "pisau bermata dua", adanya trend positif tersebut masih harus dikaji, apakah berdasarkan adanya tax amnesty dan atau kah tax planning yang mulai dijalankan, sisi negatif tax amnesty adalah fakta bahwa wajib pajak berkategori "bandel" dalam kedisiplinannya membayar pajak.

Dessy (2013:37) dengan adanya perencanaan pajak (tax planning) maka wajib pajak dapat menghematpajak yang sebenarnya melebihi kewajibannya, dan di lain pihak membantu wajib pajak dalam pengambilan keputusan yang berkaitan dengan rencana investasi di masa mendatang. Dalam melakukan perencanaan pajak, Keputusan dan Surat edaran Peraturan Perpajakan harus diikuti, dipahami, dan dipelajari secara seksama, sehingga perusahaan terhindar dari sanksi administrasi maupun sanksi pidana serta dapat melihat "celah-celah" yang menguntungkan untuk dilakukan penghematan pajak agar upaya mengefisiensikan beban pajak penghasilan badan tercapai, sehingga pajak penghasilan badan yang di bayarkan lebih rendah jika dibandingkan sebelum dilakukannnya perencanaan pajak (tax planning), dengan adanya tax planning perusahaan juga dapat menghindari pemborosan pembayaran pajak dengan mengoptimalisasi alokasi sumber daya perusahaan yang lebihproduktif dan efisien sehingga dapat memaksimalkan kinerja perusahaan. Sepanjang hal tersebut masih sesuai dengan aturan-aturan perpajakan yang berlaku.

Kota Lubuklinggau dan Kota Bengkulu merupakan dua Kota yang berbeda secara karakteristik dan demografi. Kota Bengkulu merupakan Ibu Kota Provinsi Bengkulu dan
Kota Lubuklinggau merupakan salah satu Kota yang berada di wilayah Provinsi Sumatera Selatan, karakteristik penduduk sebagai Ibu Kota Provinsi dan tidak diidentifikasi akan memiliki perbedaan karakter, indikator penunjangnya diantaranya (UMR yang berbeda; PAD Kota yang berbeda; Kuantitas izin usaha yang tidak sama; Target capaian yang berbeda; Luas lapangan kerja; dan indikator mikto lainnya yang sejenis). Perbedaan perbedaan itu tentu memberikan dampak, salah satunya adalah ketaatan pembayaran pajak penghasilan badan usaha (CV). Indikator yang lebih baik biasanya akan memberikan dampak yang lebih baik, misal dalam pembayaran pajak penghasilan, Kota yang memiliki indikator yang lebih baik tentu akan menghasilkan proses perencaaan pajak yang lebih baik. Perencanaan pajak (tax planning) sendiri akan membantu semua persekutuan komanditer (CV) baik di Kota Lubuklinggau maupun di Kota Bengkulu melakukan efisiensi pembayaran pajaknya, selain itu dengan perencanaan pajak (tax planning) juga dapat menghindari pemborosan pembayaran pajak dengan mengoptimalisasi alokasi sumber daya perusahaan yang lebih produktif dan dapat mengatur aliran kas dan dapat menyusun anggaran kas secara lebih akurat dan terperinci. Untuk membuktikan hal tersebut, maka perlu diketahui bagaimana pengelolaan Tax planning atas pajak penghasilan badan pada Perusahaan Komanditer (CV) itu sendiri.

\section{Tinjauan Pustaka \\ Teori-teori yang mendukung}

Undang-Undang No.7 Tahun 1983

Tentang Pajak Penghasilan sebagaimana telah beberapa kali diubah terakhir dengan UndangUndang No. 36 Tahun 2008 dalam BAB II Subjek Pajak Pasal 2 Yang menjadi subjek Pajak adalah : 
1. (1) Orang pribadi; (2). Warisan yang belum terbagi sabagai satu kesatuan yang menggantikan yang berhak;

2. Badan

Badan adalah sekumpulan orang dan atau modal yang merupakan kesatuan baik yang melakukan usaha maupun yang tidak melakukan usaha yang meliputi Perseroan terbatas (PT), Perseroan / Persekutuan komanditer (CV), perseroan lainnya, badan usaha milik negara atau badan usaha milik daerah dengan najma dan dalam bentuk apapun, firma, kongsi, koperasi, dana pensiun, persekutuan, perkumpulan, yayasan, organisasi massa, organisasi sosial politik atau organisasi lainnya, lembaga dan bentuk badan lainnya termasuk kontrak investasi kolektif dan bentuk usaha tetap.

\section{Bentuk Usaha tetap}

Suandy (2008:6) Perencanaan pajak adalah langkah awal dalam manajemen pajak. Pada tahap ini dilakukan pengumpulan dan penelitian terhadap peraturan perpajakan agar dapat diseleksi jenis tindakan penghematan pajak yang akan dilakukan. Pada umumnya penekanan perencanaan pajak adalah untuk meminimukan kewajiban pajak. Perencanaan pajak pada umumnya selalu dimulai dengan meyakinkan apakah suatu transaksi atau fenomena terkena pajak. Kalau fenomena tersebut terkena pajak, apakah dapat diupayakan untuk dikecualikan atau dikurangi pajaknya, selanjutnya apakah pembayaran dimaksud dapat ditanda pembayarannya, dan lain sebagainya. Suandy (2008:13) mengatakan dalam arus globalisasi dan tingkat persaingan yang semakin tinggi, seorang manajer dalam membuat suatu perencanaan pajak sebagaiana strategi perencanaan perusahaan secara keseluruhan harus memperhitungkan adanya kegiatan yang bersifat lokal maupun internasional. Agar perencanaan pajak dapat berhasil sesuai dengan yang diharapkan., maka rencana itu seharusnya dilakukan melalui urutan (1) Menganalisis informasi yang ada; (2) Buat satu model atau lebih rencana besarnya pajak; (3) Penggunaan satu atau lebih negara tambahan; (4) Evaluasi atas perencanaan pajak; (5) Mencari kelemahan kemudian memperbaiki kembali rencana pajak; dan (6) Memutakhirkan rencana pajak.

\section{Undang-Undang yang mendasari}

Perencanaan Pajak (Tax Planning).

Undang-undang yang mendasari dalam melakukan perencanaan pajak (tax planning)adalah Undang-Undang No.36 Tahun 2008. Undang-Undang No.36 Tahun 2008 adalah peraturan perpajakan yang mengatur tentang pajak pengenaan pajak penghasilan kepada badan dan orang pribadi yang mulai berlaku sejak tanggal 1 Januari 2008.

Hasil Penelitian yang Terdahulu yang relevan

Laorens Silitonga, 2013, dengan judul penelitian Penerapan Tax Planning Atas Pajak Penghasilan Badan Pada CV. Andi Offset Cabang Manado, Hasilnya Efisiensi terhadap pajak penghasilan badan yang terutang dapat dilakukan dengan cara : pemanfaatan pengembangan dan pendidikan SDM, diadakan pos khusus untuk tunjangan pensiun, biaya pembelian telepon seluler dan pengisian pulsa terkait dengan jabatan pekerjaan. Dan yang terakhir peniadaan fasilitas mobil dinas yang bisa menambah biaya pemeliharaan sehingga efisiensi pajak berhasil di lakukan.

Sri komalasari 2012, dengan judul penelitian Analisis Perencanaan Pajak (Tax Planning) atas pajak penghasilan badan Pada PT. Lau Linggau, Hasilnya Efisiensi terhadap pajak penghasilan badan yang terutang dapat dilakukan dengan cara: pemberian pengembangan SD dan pendidikan bagi karyawan sopir/kernet, pebmberian bonus atas prestasi kerja, pemberian tunjangan kesehatan karyawan, pemberian pakaian kerja karyawan. Efisiensi yang dapat diperoleh dari perencanaan pajak pada penelitian ini dengan memanfaatkan peraturan perundangundangan perpajakan PPh No. 36 tahun 2008.

Indah Yulia Puspitasari 2011, dengan judul penelitian Penerapan Tax Planning Atas Pajak Penghasilan Badan (studi kasus CV. Scronica Sari), HasilnyEfisiensi terhadap pajak penghasilan badan yang terutang dapat dilakukan dengan cara: pemberian tunjangan kesehatan bagi karyawan, pemberian bonus tambahan bagi karyawan dan pemberian kendaraan operasional. Efisiensi yang dapat diperoleh dari perencanaan pajak pada penelitian ini dengan memanfaatkan peraturan perundangundangan perpajakan PPh No. 36 tahun 2008 
adalah sebesar Rp. 2.970 .000 dan dalam penghematan pajaknya adalah sebesar $11,4 \%$.

\section{Metode Penelitian \\ Jenis Penelitian}

Siregar (2012:9) jenis penelitian dapat digolongkan kedalam beberapa jenis berdasarkan kriteria-kriteria tertentu, pada penelitian ini peneliti menggunakan jenis penelitian deskriptif, dimana peneliti akan menganalisis tahap-tahap perencanaan pajak (tax planning) atas pajak penghasilan badan dan akan membandingkan laporan laba rugi antara sebelum melakukan perencanaan pajak dan dengan mempertimbangkan tindakantindakan yang sebaiknya diambil dalam mengefisiensikan Pajak Penghasilan Badan terutang tahun 2015 berdasarkan UndangUndang No. 36 tahun 2008 pasal 9 ayat (1) dan Undang-Undang No. 36 tahun 2006 pasal 9 ayat (1) huruf e, maka dapat dilakukan kegiatan - kegiatan sebagai berikut : (tax planning) dan laporan laba rugi sesudah melakukan perencanaan pajak (tax planning) untuk mengetahui efisiensi pajak yang telah dilakukan.

\section{Teknik Pengumpulan Data}

Arikunto (2010:193) merujuk itu, maka metode yang digunakan dalam penelitian ini adalah Observasi, Dokumentasi dan Wawancara.

\section{Teknik Analisis Data}

Sunyoto (2013:24-26) teknik analisis data yang digunakan yaitu data kualitatif dan data kuantitatif. peneliti dalam penelitian ini menggunakan analisis kualitatif

1. Pemberian tunjangan kesehatan untuk karyawan

2. Pemberian pengembangan SDM dan pendidikan bagi karyawan.

3. Pemberian bonus atas prestasi kerja karyawan.

4. Pemberian kendaraan untuk alat transportasi

5. Pemberian seragam untuk karyawan.

\section{Hasil Penelitian}

Tabel 2 : Analisa Efisiensi PPH Badan CV Wilayah Kota Lubuklinggau

\begin{tabular}{|c|c|c|c|c|}
\hline Nama CV & \multicolumn{4}{|c|}{ Pemberian } \\
\hline CV Mura Laduni & Tunjangan Kesehatan & $\begin{array}{ll}\text { Pengembangan } & \text { SDM } \\
\text { dan Pendidikan }\end{array}$ & Bonus & $\begin{array}{l}\text { Kendaraan dan } \\
\text { Seragam }\end{array}$ \\
\hline Keterangan & Tidak & $\mathrm{Ya}$ & $\mathrm{Ya}$ & $\begin{array}{ll}\text { Kendaraan } & \text { Ya, } \\
\text { Seragam Tidak } & \end{array}$ \\
\hline Alasan & Karyawan Tidak Tetap & $\begin{array}{l}\text { CV membutuhkan Skill } \\
\text { SDM }\end{array}$ & $\begin{array}{l}\text { Disesuaikan } \\
\text { dengan beban kerja }\end{array}$ & $\begin{array}{l}\text { Kendaran diberikan } \\
\text { untuk } \\
\text { mempermudah } \\
\text { pekerjaan }\end{array}$ \\
\hline Jumlah Pekerja & 0 & Tergantung Kebutuhan & $\begin{array}{l}\text { Diberikan kepada } \\
\text { Siapa yang bekerja }\end{array}$ & $\begin{array}{l}\text { Tergantung } \\
\text { kebutuhan }\end{array}$ \\
\hline Nama CV & \multicolumn{4}{|c|}{ Pemberian } \\
\hline $\begin{array}{l}\text { CV Rawas Central } \\
\text { Multimedia }\end{array}$ & Tunjangan Kesehatan & $\begin{array}{l}\text { Pengembangan } \\
\text { dan Pendidikan }\end{array}$ & Bonus & $\begin{array}{l}\text { Kendaraan dan } \\
\text { Seragam }\end{array}$ \\
\hline Keterangan & $\begin{array}{l}\text { Tidak, Hanya Tunjangan } \\
\text { BPJS Ketenagkerjaan }\end{array}$ & Ya & $\mathrm{Ya}$ & $\begin{array}{ll}\text { Kendaraan } & \text { Ya, } \\
\text { Seragam Tidak } & \\
\end{array}$ \\
\hline Alasan & Karyawan Tidak Tetap & $\begin{array}{l}\text { CV Membutuhkan Skill } \\
\text { SDM }\end{array}$ & $\begin{array}{l}\text { Hanya } \quad \text { untuk } \\
\text { pekerja yang } \\
\text { mencapai target }\end{array}$ & $\begin{array}{l}\text { Kendaran diberikan } \\
\text { untuk } \\
\text { mempermudah } \\
\text { pekerjaan }\end{array}$ \\
\hline Jumlah Pekerja & 0 & Tergantung Kebutuhan & Situasional & $\begin{array}{l}\text { Tergantung } \\
\text { kebutuhan }\end{array}$ \\
\hline Nama CV & \multicolumn{4}{|c|}{ Pemberian } \\
\hline CV Mebel R Dika & Tunjangan Kesehatan & $\begin{array}{ll}\begin{array}{l}\text { Pengembangan } \\
\text { dan Pendidikan }\end{array} & \\
\end{array}$ & Bonus & $\begin{array}{l}\text { Kendaraan dan } \\
\text { Seragam }\end{array}$ \\
\hline Keterangan & Tidak & Tidak & $\mathrm{Ya}$ & $\begin{array}{l}\text { Seragam Ya, } \\
\text { Kendaran Tidak }\end{array}$ \\
\hline Alasan & $\begin{array}{l}\text { CV Belum mampu, tetapi } \\
\text { akan memberikan } \\
\text { bantuan apabila ada } \\
\text { pekerja atau keluarganya } \\
\text { yang sakit }\end{array}$ & $\begin{array}{l}\text { Sejak Rekrutmen, CV } \\
\text { hanya menerima tenaga } \\
\text { ahli sesuai dengan } \\
\text { karakter CV }\end{array}$ & $\begin{array}{l}\text { Pemberian Bonus } \\
\text { berdasarkan } \\
\text { lembur }\end{array}$ & $\begin{array}{ll}\text { Seragam } & \text { sebagai } \\
\text { identitas } & \text { kepada } \\
\text { pelanggan } & \end{array}$ \\
\hline Jumlah Pekerja & Situasional & 0 & Semua Karyawan & Semua Karyawan \\
\hline Nama CV & \multicolumn{4}{|c|}{ Pemberian } \\
\hline
\end{tabular}




\begin{tabular}{|c|c|c|c|c|}
\hline CV Verry Mebel & Tunjangan Kesehatan & $\begin{array}{ll}\begin{array}{l}\text { Pengembangan } \\
\text { dan Pendidikan }\end{array} & \\
\end{array}$ & Bonus & $\begin{array}{l}\text { Kendaraan dan } \\
\text { Seragam }\end{array}$ \\
\hline Keterangan & Ya & Ya & $\mathrm{Ya}$ & $\begin{array}{ll}\text { Kendaraan } & \text { Ya, } \\
\text { Seragam Tidak } & \end{array}$ \\
\hline Alasan & $\begin{array}{ll}\text { Diberikan } & \text { melalui } \\
\text { Jamsostek } & \end{array}$ & $\begin{array}{l}\text { Proses magang saat baru } \\
\text { mulai bekerja di CV }\end{array}$ & $\begin{array}{lr}\text { Apabila } & \mathrm{CV} \\
\text { mendapat } & \text { pesanan } \\
\text { berlebih } & \text { makan } \\
\text { pekerja } & \text { akan } \\
\text { siberikan } & \text { bonus } \\
\text { yang sesuai } & \\
\end{array}$ & $\begin{array}{lr}\text { Kendaraan } & \\
\text { diberikan kepada } \\
\text { pekerja } \\
\text { memang } \\
\text { dibidangnya } \\
\text { membutuhkan } \\
\end{array}$ \\
\hline Jumlah Pekerja & Semua Karyawan & Semua Karyawan & Semua Karyawan & Situasional \\
\hline Nama CV & \multicolumn{4}{|c|}{ Pemberian } \\
\hline CV MAP Ekpedisi & Tunjangan Kesehatan & $\begin{array}{l}\text { Pengembangan } \text { SDM } \\
\text { dan Pendidikan }\end{array}$ & Bonus & $\begin{array}{l}\text { Kendaraan dan } \\
\text { Seragam }\end{array}$ \\
\hline Keterangan & Ya & Ya & Ya & $\begin{array}{ll}\text { Kendaraan } & \text { Ya, } \\
\text { Seragam Ya } & \\
\end{array}$ \\
\hline Alasan & $\begin{array}{l}\text { Tunjangan Kesehatan } \\
\text { Pribdi Pekerja }\end{array}$ & $\begin{array}{l}\text { Untuk pengembangan } \\
\text { SDM }\end{array}$ & $\begin{array}{l}\text { Diberikan } \\
\text { tunjangan berupa } \\
\text { THR }\end{array}$ & $\begin{array}{lr}\text { Kendaraan } \\
\text { diberikan } \\
\text { driver, dan Seragam } \\
\text { diberikan } \\
\begin{array}{lr}\text { kepada hanya } \\
\text { tetap }\end{array} \\
\end{array}$ \\
\hline Jumlah Pekerja & Semua Karyawan & $\begin{array}{l}1 \text { Karyawan per sekali } \\
\text { kegiatan }\end{array}$ & Semua Karyawan & $\begin{array}{ll}\text { Semua } & \text { Karyawan } \\
\text { Tetap } & \\
\end{array}$ \\
\hline Nama CV & \multicolumn{4}{|c|}{ Pemberian } \\
\hline CV Makmur Jaya & Tunjangan Kesehatan & $\begin{array}{ll}\begin{array}{l}\text { Pengembangan } \\
\text { dan Pendidikan }\end{array} & \\
\end{array}$ & Bonus & $\begin{array}{l}\text { Kendaraan dan } \\
\text { Seragam }\end{array}$ \\
\hline Keterangan & Ya & Tidak & $\mathrm{Ya}$ & $\begin{array}{ll}\text { Kendaraan } & \text { Ya, } \\
\text { Seragam Tidak } & \end{array}$ \\
\hline Alasan & $\begin{array}{l}\text { Tunjangan berupa BPJS } \\
\text { Kesehatan }\end{array}$ & $\begin{array}{lr}\text { Sejak } & \text { Rekrutmen } \\
\text { hanya } & \text { menerima } \\
\text { karyawan } & \text { yang } \\
\text { mempunyai } & \text { skill } \\
\text { dibidangnya } & \end{array}$ & $\begin{array}{l}\text { Berupa Tunjangan } \\
\text { THR }\end{array}$ & $\begin{array}{l}\text { Kendaraan } \\
\text { diberikan sesuai } \\
\text { dengan kebutuhan }\end{array}$ \\
\hline Jumlah Pekerja & Semua Karyawan & Semua Karyawan & Semua Karyawan & Semua Karyawan \\
\hline Nama CV & \multicolumn{4}{|c|}{$\begin{array}{c}\text { Pemberian } \\
\end{array}$} \\
\hline CV Asoka Travel & Tunjangan Kesehatan & $\begin{array}{ll}\text { Pengembangan } & \text { SDM } \\
\text { dan Pendidikan } & \end{array}$ & Bonus & $\begin{array}{l}\text { Kendaraan dan } \\
\text { Seragam }\end{array}$ \\
\hline Keterangan & Ya & Tidak & Tidak & $\begin{array}{ll}\text { Kendaraan } & \text { Ya, } \\
\text { Seragam Tidak } & \\
\end{array}$ \\
\hline Alasan & $\begin{array}{l}\text { Berupa } \text { Asuransi karena } \\
\text { jenis pekerjaannya } \\
\text { adalah travel }\end{array}$ & $\begin{array}{lr}\text { Sejak } & \text { Rekrutmen } \\
\text { hanya } & \text { menerima } \\
\text { karyawan } & \text { yang } \\
\text { mempunyai } & \text { skill } \\
\text { dibidangnya } & \\
\end{array}$ & $\begin{array}{ll}\text { Karyawan } & \text { Tidak } \\
\text { Tetap } & \end{array}$ & $\begin{array}{l}\text { Kendaraan } \\
\text { diberikan sesuai } \\
\text { dengan fungsi CV }\end{array}$ \\
\hline Jumlah Pekerja & Semua Karyawan & Semua Karyawan & 0 & Semua Karyawan \\
\hline Nama CV & \multicolumn{4}{|c|}{$\begin{array}{c}\text { Pemberian } \\
\end{array}$} \\
\hline CV Mandiri Jaya & Tunjangan Kesehatan & $\begin{array}{ll}\text { Pengembangan } & \text { SDM } \\
\text { dan Pendidikan } & \end{array}$ & Bonus & $\begin{array}{l}\text { Kendaraan dan } \\
\text { Seragam }\end{array}$ \\
\hline Keterangan & Ya & Tidak & Tidak & $\begin{array}{ll}\text { Kendaraan } & \text { Ya, } \\
\text { Seragam Tidak } & \\
\end{array}$ \\
\hline Alasan & $\begin{array}{l}\text { Berupa BPJS Keseshatan } \\
\text { untuk K3 }\end{array}$ & $\begin{array}{l}\text { Karyawan dibiarkan } \\
\text { berkembang } \\
\text { berdasarkan } \\
\text { pengalaman kerja saja }\end{array}$ & & $\begin{array}{lr}\text { Kendaraan } & \\
\text { diberikan } & \text { sesuai } \\
\text { dengan } & \text { bidang } \\
\text { kerjanya } & \\
\end{array}$ \\
\hline Jumlah Pekerja & Semua Karyawan Tetap & 0 & 0 & Situasional \\
\hline Nama CV & \multicolumn{4}{|c|}{ Pemberian } \\
\hline CV Gold Developer & Tunjangan Kesehatan & $\begin{array}{ll}\text { Pengembangan } & \text { SDM } \\
\text { dan Pendidikan } & \\
\end{array}$ & Bonus & $\begin{array}{l}\text { Kendaraan dan } \\
\text { Seragam }\end{array}$ \\
\hline Keterangan & $\mathrm{Ya}$ & Tidak & $\mathrm{Ya}$ & $\begin{array}{ll}\text { Kendaraan } & \text { Ya, } \\
\text { Seragam Tidak } & \\
\end{array}$ \\
\hline Alasan & $\begin{array}{l}\text { Jaminan Kesehatan Kerja } \\
\text { dengan BPJS Kesehatan }\end{array}$ & & $\begin{array}{l}\text { Tunjangan berupa } \\
\text { THR }\end{array}$ & $\begin{array}{l}\text { Digunakan untuk } \\
\text { keperluan usaha }\end{array}$ \\
\hline Jumlah Pekerja & Semua Pekerja & 0 & Semua Karyawan & Semua Karyawan \\
\hline Nama CV & \multicolumn{4}{|c|}{ Pemberian } \\
\hline $\begin{array}{l}\text { CV Cahaya Alim } \\
\text { Perkasa }\end{array}$ & Tunjangan Kesehatan & $\begin{array}{ll}\begin{array}{l}\text { Pengembangan } \\
\text { dan Pendidikan }\end{array} & \\
\end{array}$ & Bonus & $\begin{array}{l}\text { Kendaraan } \\
\text { Seragam }\end{array}$ \\
\hline
\end{tabular}




\begin{tabular}{|c|c|c|c|c|}
\hline Keterangan & Tidak & Tidak & $\mathrm{Ya}$ & $\begin{array}{ll}\text { Kendaraan } & \text { Ya, } \\
\text { Seragam Tidak } & \end{array}$ \\
\hline Alasan & $\begin{array}{l}\text { Karena Semua Karyawan } \\
\text { tidak tetap }\end{array}$ & $\begin{array}{l}\text { Sejak Rekrutmen hanya } \\
\text { menerima pekerja yang } \\
\text { ahli sesuai dengan } \\
\text { kebutuhan CV }\end{array}$ & $\begin{array}{l}\text { Diberikan karena } \\
\text { berupa bonus } \\
\text { mencapai target }\end{array}$ & $\begin{array}{l}\text { Diberikan } \\
\text { kendaraan karena } \\
\text { memang kebutuhan } \\
\text { CV untuk pekerja }\end{array}$ \\
\hline Jumlah Pekerja & 0 & & Semua Karyawan & Semua Karyawan \\
\hline Nama CV & \multicolumn{4}{|c|}{ Pemberian } \\
\hline CV Tri Agung & Tunjangan Kesehatan & $\begin{array}{ll}\text { Pengembangan } & \text { SDM } \\
\text { dan Pendidikan } & \end{array}$ & Bonus & $\begin{array}{l}\text { Kendaraan dan } \\
\text { Seragam }\end{array}$ \\
\hline Keterangan & $\mathrm{Ya}$ & Tidak & $\mathrm{Ya}$ & $\begin{array}{ll}\text { Kendaraan } & \text { Ya, } \\
\text { Seragam Ya } & \end{array}$ \\
\hline Alasan & $\begin{array}{lr}\text { Jaminan } & \text { Kesehatan } \\
\text { dengan } & \text { memberikan } \\
\text { BPJS } & \end{array}$ & & $\begin{array}{lr}\text { Berupa } & \begin{array}{r}\text { Bonus } \\
\text { Uang }\end{array} \\
\text { Traveling } & \\
\text { (Mencapai } & \text { Target } \\
\text { Penjualan) } & \\
\end{array}$ & $\begin{array}{lr}\text { Kendaraan } & \text { dan } \\
\text { Seragam } & \text { diberikan } \\
\text { karena } & \text { sudah } \\
\text { memang } & \text { program } \\
\text { CV } & \\
\end{array}$ \\
\hline Jumlah Pekerja & Karyawan Tetap & 0 & $\begin{array}{l}\text { Semua Karyawan } \\
\text { Tetap }\end{array}$ & $\begin{array}{ll}\text { Semua } & \text { Karyawan } \\
\text { Tetap } & \\
\end{array}$ \\
\hline Nama CV & \multicolumn{4}{|c|}{ Pemberian } \\
\hline $\begin{array}{ll}\text { CV } & \text { Universal } \\
\text { Mandri } & \end{array}$ & Tunjangan Kesehatan & $\begin{array}{l}\text { Pengembangan } \\
\text { dan Pendidikan }\end{array}$ & Bonus & $\begin{array}{l}\text { Kendaraan dan } \\
\text { Seragam }\end{array}$ \\
\hline Keterangan & Tidak & $\mathrm{Ya}$ & $\mathrm{Ya}$ & $\begin{array}{l}\text { Kendaraan Tidak, } \\
\text { Seragam Tidak }\end{array}$ \\
\hline Alasan & $\begin{array}{l}\text { Karena Karyawan } \\
\text { semuanya kontrak }\end{array}$ & $\begin{array}{l}\text { Sebagai programkerja } \\
\text { CV untuk membentuk } \\
\text { tenaga kerja yang handal }\end{array}$ & $\begin{array}{l}\text { Apabila karyawan } \\
\text { memenuhi target } \\
\text { yang ditentukan }\end{array}$ & $\begin{array}{l}\text { Dikarenakan sesuai } \\
\text { dengan jenis } \mathrm{CV}\end{array}$ \\
\hline Jumlah Pekerja & 0 & Situasional & Situasional & 0 \\
\hline Nama CV & \multicolumn{4}{|c|}{$\begin{array}{c}\text { Pemberian } \\
\end{array}$} \\
\hline CV Roti Tiga Berlian & Tunjangan Kesehatan & $\begin{array}{l}\text { Pengembangan } \\
\text { dan Pendidikan }\end{array}$ & Bonus & $\begin{array}{l}\text { Kendaraan dan } \\
\text { Seragam }\end{array}$ \\
\hline Keterangan & Tidak & Ya & $\mathrm{Ya}$ & $\begin{array}{l}\text { Kendaraan Tidak, } \\
\text { Seragam Ya }\end{array}$ \\
\hline Alasan & $\begin{array}{lr}\text { Karyawan } & \text { yang } \\
\text { diperkerjakan } & \text { Karyawan } \\
\text { tidak tetap } & \end{array}$ & $\begin{array}{l}\text { Pelatihan dalam rangka } \\
\text { peningkatan } \\
\text { keterampilan }\end{array}$ & $\begin{array}{lr}\text { Dilakukan sebagai } \\
\text { bentuk } \\
\text { penghargaan untuk } \\
\text { karyawan yang } \\
\text { berprestasi }\end{array}$ & $\begin{array}{l}\text { Diberikan seragam } \\
\text { untuk memupuk } \\
\text { rasa percaya diri dan } \\
\text { kekompakkan }\end{array}$ \\
\hline Jumlah Pekerja & 0 & Situasional & Situasional & Semua Karyawan \\
\hline Nama CV & \multicolumn{4}{|c|}{ Pemberian } \\
\hline CV Lau Manis & Tunjangan Kesehatan & $\begin{array}{l}\text { Pengembangan } \\
\text { dan Pendidikan }\end{array}$ & Bonus & $\begin{array}{l}\text { Kendaraan dan } \\
\text { Seragam }\end{array}$ \\
\hline & \multicolumn{4}{|c|}{$\begin{array}{l}\text { Dari sisi pendekatan data sekunder (laporan laba rugi dan neraca) CV ini tidak mencantumkan } \\
\text { pengeluaran dalam bentuk (Tunjangan Keseahatan, Pengembangan SDM, Pemberian Bonus, } \\
\text { Pemberian Seragam dan Kendaraan) sehingga peneliti dan tim membuat kesimpulan bahwa CV ini } \\
\text { tidak melakukan aktivitas tersebut }\end{array}$} \\
\hline Nama CV & \multicolumn{4}{|c|}{ Pemberian } \\
\hline $\begin{array}{l}\text { CV Makmur } \\
\text { Sejahtera Abadi }\end{array}$ & Tunjangan Kesehatan & $\begin{array}{l}\text { Pengembangan } \\
\text { dan Pendidikan }\end{array}$ & Bonus & $\begin{array}{l}\text { Kendaraan dan } \\
\text { Seragam }\end{array}$ \\
\hline & \multicolumn{4}{|c|}{$\begin{array}{l}\text { Dari sisi pendekatan data sekunder (laporan laba rugi dan neraca) CV ini secara umum } \\
\text { mencantumkan pengeluaran dalam bentuk (Tunjangan Keseahatan, Pengembangan SDM, Pemberian } \\
\text { Bonus, Pemberian Seragam dan Kendaraan) sehingga peneliti dan tim membuat kesimpulan bahwa } \\
\text { CV melakukan aktivitas tersebut tetapi dengan keterbatasanya }\end{array}$} \\
\hline Nama CV & \multicolumn{4}{|c|}{ Pemberian } \\
\hline CV Mutiara Intan & Tunjangan Kesehatan & $\begin{array}{ll}\begin{array}{l}\text { Pengembangan } \\
\text { dan Pendidikan }\end{array} & \\
\end{array}$ & Bonus & $\begin{array}{l}\text { Kendaraan dan } \\
\text { Seragam }\end{array}$ \\
\hline & \multicolumn{4}{|c|}{$\begin{array}{l}\text { Dari sisi pendekatan data sekunder (laporan laba rugi dan neraca) CV ini secara umum } \\
\text { mencantumkan pengeluaran dalam bentuk (Tunjangan Keseahatan, Pengembangan SDM, Pemberian } \\
\text { Bonus, Pemberian Seragam dan Kendaraan) sehingga peneliti dan tim membuat kesimpulan bahwa } \\
\text { CV melakukan aktivitas tersebut tetapi dengan keterbatasanya }\end{array}$} \\
\hline Nama CV & \multicolumn{4}{|c|}{ Pemberian } \\
\hline $\begin{array}{ll}\text { CV } & \text { Bintang } \\
\text { Ramadhan } & \end{array}$ & Tunjangan Kesehatan & $\begin{array}{l}\text { Pengembangan } \\
\text { dan Pendidikan }\end{array}$ & Bonus & $\begin{array}{l}\text { Kendaraan dan } \\
\text { Seragam }\end{array}$ \\
\hline & \multicolumn{4}{|c|}{$\begin{array}{l}\text { Dari sisi pendekatan data sekunder (laporan laba rugi dan neraca) CV ini secara umum } \\
\text { mencantumkan pengeluaran dalam bentuk (Tunjangan Keseahatan, Pengembangan SDM, Pemberian } \\
\text { Bonus, Pemberian Seragam dan Kendaraan) sehingga peneliti dan tim membuat kesimpulan bahwa } \\
\text { CV melakukan aktivitas tersebut tetapi dengan keterbatasanya }\end{array}$} \\
\hline
\end{tabular}




\begin{tabular}{|c|c|c|c|c|}
\hline Nama CV & \multicolumn{4}{|l|}{ Pemberian } \\
\hline \multirow[t]{2}{*}{ CV Dekha } & Tunjangan Kesehatan & $\begin{array}{l}\text { Pengembangan SDM } \\
\text { dan Pendidikan }\end{array}$ & Bonus & $\begin{array}{l}\text { Kendaraan dan } \\
\text { Seragam }\end{array}$ \\
\hline & \multicolumn{4}{|c|}{$\begin{array}{l}\text { Dari sisi pendekatan data sekunder (laporan laba rugi dan neraca) CV ini secara umum } \\
\text { mencantumkan pengeluaran dalam bentuk (Tunjangan Keseahatan, Pengembangan SDM, Pemberian } \\
\text { Bonus, Pemberian Seragam dan Kendaraan) sehingga peneliti dan tim membuat kesimpulan bahwa } \\
\text { CV melakukan aktivitas tersebut tetapi dengan keterbatasanya }\end{array}$} \\
\hline Nama CV & \multicolumn{4}{|c|}{ Pemberian } \\
\hline $\begin{array}{l}\text { CV Remban Putra } \\
\text { Media }\end{array}$ & Tunjangan Kesehatan & $\begin{array}{ll}\text { Pengembangan } & \text { SDM } \\
\text { dan Pendidikan } & \\
\end{array}$ & Bonus & $\begin{array}{l}\text { Kendaraan dan } \\
\text { Seragam }\end{array}$ \\
\hline & \multicolumn{4}{|c|}{$\begin{array}{l}\text { Dari sisi pendekatan data sekunder (laporan laba rugi dan neraca) CV ini secara umum } \\
\text { mencantumkan pengeluaran dalam bentuk (Tunjangan Keseahatan, Pengembangan SDM, Pemberian } \\
\text { Bonus, Pemberian Seragam dan Kendaraan) sehingga peneliti dan tim membuat kesimpulan bahwa } \\
\text { CV melakukan aktivitas tersebut tetapi dengan keterbatasanya }\end{array}$} \\
\hline Nama CV & \multicolumn{4}{|c|}{ Pemberian } \\
\hline CV Sahabat & Tunjangan Kesehatan & $\begin{array}{ll}\text { Pengembangan } & \text { SDM } \\
\text { dan Pendidikan } & \\
\end{array}$ & Bonus & $\begin{array}{l}\text { Kendaraan dan } \\
\text { Seragam }\end{array}$ \\
\hline & \multicolumn{4}{|c|}{$\begin{array}{l}\text { Dari sisi pendekatan data sekunder (laporan laba rugi dan neraca) CV ini secara umum } \\
\text { mencantumkan pengeluaran dalam bentuk (Tunjangan Keseahatan, Pengembangan SDM, Pemberian } \\
\text { Bonus, Pemberian Seragam dan Kendaraan) sehingga peneliti dan tim membuat kesimpulan bahwa } \\
\text { CV melakukan aktivitas tersebut tetapi dengan keterbatasanya }\end{array}$} \\
\hline
\end{tabular}

Sumber : Peneliti, 2018

V melakukan aktivitas tersebut tetapi dengan keterbatasanya

Tabel 3 : Analisa Efisiensi PPH Badan CV Wilayah Kota Bengkulu

\begin{tabular}{|c|c|c|c|c|}
\hline Nama CV & \multicolumn{4}{|c|}{ Pemberian } \\
\hline CV. Duta Pratama & $\begin{array}{l}\text { Tunjangan } \\
\text { Kesehatan }\end{array}$ & $\begin{array}{l}\text { Pengembangan } \\
\text { SDM dan } \\
\text { Pendidikan }\end{array}$ & Bonus & $\begin{array}{l}\text { Kendaraan } \\
\text { Seragam }\end{array}$ \\
\hline Keterangan & Iya & iya & Iya & Iya \\
\hline Alasan & $\begin{array}{l}\text { Untuk membantu } \\
\text { karyawan, apabila ada } \\
\text { yang sakit. }\end{array}$ & $\begin{array}{l}\text { CV. memberikan } \\
\text { pelatihan untuk } \\
\text { pengembangan } \\
\text { kinerja karyawaan }\end{array}$ & $\begin{array}{lr}\text { CV. memberikan } \\
\text { bonus } & \text { kepada } \\
\text { karyawan } & \text { yang } \\
\text { lembur. } & \\
\end{array}$ & $\begin{array}{l}\text { CV. menyediakan } \\
\text { seragam dan kendaraan } \\
\text { agar terjadi kenyamanan } \\
\text { dan kekompakan. }\end{array}$ \\
\hline Jumlah Pekerja & 6 orang & 6 orang & 6 orang & 6 orang \\
\hline Nama CV & \multicolumn{4}{|c|}{$\begin{array}{r}\text { Pemberian } \\
\end{array}$} \\
\hline $\begin{array}{l}\text { CV. Utama Motor } \\
\text { Pagardewa }\end{array}$ & $\begin{array}{l}\text { Tunjangan } \\
\text { Kesehatan }\end{array}$ & $\begin{array}{ll}\text { Pengembangan } & \\
\text { SDM dan } \\
\text { Pendidikan }\end{array}$ & Bonus & $\begin{array}{l}\text { Kendaraan } \\
\text { Seragam }\end{array}$ \\
\hline Keterangan & Tidak & Tidak & Iya & Iya \\
\hline Alasan & 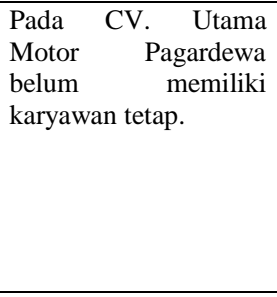 & $\begin{array}{lr}\text { CV. Utama } & \text { Motor } \\
\text { Pagardewa tidak } \\
\text { memberikan } \\
\text { pengembangan SDM } \\
\text { dan Pendidikan } \\
\text { kepada karyawan. }\end{array}$ & $\begin{array}{l}\text { CV. Utama Motor } \\
\text { Pagardewa } \\
\text { memberikan } \\
\text { bonus kepada } \\
\text { karyawan ketika } \\
\text { melebihi target, } \\
\text { lembur, dan } \\
\text { orderan sedang } \\
\text { banyak. }\end{array}$ & $\begin{array}{l}\text { CV. Utama Motor } \\
\text { Pagardewa memberikan } \\
\text { seragam kepada setiap } \\
\text { karyawan nya }\end{array}$ \\
\hline Jumlah Pekerja & 0 & 0 & $\begin{array}{l}\text { Hanya karyawan } \\
\text { tetap }\end{array}$ & Semua karyawan \\
\hline Nama CV & \multicolumn{4}{|c|}{ Pemberian } \\
\hline CV. Sukamerindu & $\begin{array}{l}\text { Tunjangan } \\
\text { Kesehatan }\end{array}$ & $\begin{array}{ll}\text { Pengembangan } & \\
\text { SDM dan } \\
\text { Pendidikan }\end{array}$ & Bonus & $\begin{array}{l}\text { Kendaraan } \\
\text { Seragam }\end{array}$ \\
\hline Keterangan & Iya & Iya & Iya & Iya \\
\hline Alasan & $\begin{array}{l}\text { CV. Sukamerindu } \\
\text { memberikan tunjangan } \\
\text { kesehatan untuk } \\
\text { mensejahterakan } \\
\text { karyawan }\end{array}$ & $\begin{array}{l}\text { CV. Sukamerindu } \\
\text { memberikan } \\
\text { pengembangan SDM } \\
\text { untuk meningkatkan } \\
\text { skill pada karyawan }\end{array}$ & $\begin{array}{l}\text { CV. Sukamerindu } \\
\text { memberikan } \\
\text { insentif jika teradi } \\
\text { banyaknya } \\
\text { peminat atau } \\
\text { penumpang di } \\
\text { CV. } \\
\text { Sukamerindu. }\end{array}$ & $\begin{array}{l}\text { Karena } \\
\text { Sukamerindu bergerak } \\
\text { pada bidang jasa atau } \\
\text { travel jadi kendaraan } \\
\text { sudah disediakan oleh } \\
\text { pihak CV. }\end{array}$ \\
\hline Jumlah Pekerja & 7 orang & 7 orang & $\begin{array}{l}\text { Pada tahun } 2017 \\
\text { ada } 3 \text { orang } \\
\text { karyawan yang }\end{array}$ & 7 orang \\
\hline
\end{tabular}




\begin{tabular}{|c|c|c|c|c|}
\hline & & & $\begin{array}{l}\text { diberikan } \\
\text { instensif. }\end{array}$ & \\
\hline Nama CV & \multicolumn{4}{|c|}{$\begin{array}{c}\text { Pemberian } \\
\end{array}$} \\
\hline $\begin{array}{ll}\text { CV. } & \text { Kreas } \\
\text { Bangunan } & \end{array}$ & $\begin{array}{l}\text { Tunjangan } \\
\text { Kesehatan }\end{array}$ & $\begin{array}{ll}\text { Pengembangan } & \\
\text { SDM dan } \\
\text { Pendidikan }\end{array}$ & Bonus & $\begin{array}{l}\text { Kendaraan } \\
\text { Seragam }\end{array}$ \\
\hline Keterangan & Tidak & Tidak & Iya & Iya \\
\hline Alasan & $\begin{array}{l}\text { CV. Kreas Bangunan } \\
\text { tidak memberikan } \\
\text { tunjangan kesehatan } \\
\text { karena keterbatasan } \\
\text { dana yang dimiliki. }\end{array}$ & $\begin{array}{l}\text { CV. Kreas Bangunan } \\
\text { tidak memberikan } \\
\text { pengembangan SDM } \\
\text { dan pendidikan karena } \\
\text { sebelum menjadi } \\
\text { karyawan harus } \\
\text { memiliki skill. }\end{array}$ & $\begin{array}{lr}\text { CV. } & \text { Kreas } \\
\text { Bangunan } & \\
\text { memberikan } \\
\text { bonus } \quad \text { dalam } \\
\text { bentuk } & \text { uang } \\
\text { apabila } & \text { melebihi } \\
\text { target. } & \\
\end{array}$ & 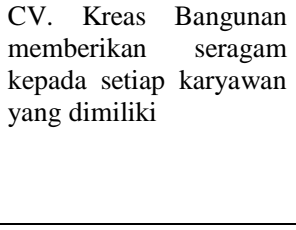 \\
\hline Jumlah Pekerja & 0 & 10 orang & 1 orang & $\begin{array}{l}\text { Semua karyawan } \mathrm{CV} . \\
\text { Kreas Bangunan }\end{array}$ \\
\hline Nama CV & \multicolumn{4}{|c|}{ Pemberian } \\
\hline CV. Abdan & $\begin{array}{l}\text { Tunjangan } \\
\text { Kesehatan }\end{array}$ & $\begin{array}{l}\text { Pengembangan } \\
\text { SDM dan } \\
\text { Pendidikan }\end{array}$ & Bonus & $\begin{array}{l}\text { Kendaraan } \\
\text { Seragam }\end{array}$ \\
\hline Keterangan & Tidak & Tidak & Iya & Iya \\
\hline Alasan & $\begin{array}{l}\text { Karena CV ini hanya } \\
\text { sekala kecil saja dan } \\
\text { dananya tidak } \\
\text { memungkinkan untuk } \\
\text { memberikan tunjangan } \\
\text { kesehatan }\end{array}$ & \begin{tabular}{lr}
\multicolumn{2}{l}{ Karena para pekerja } \\
$\mathrm{CV}$. Abdan \\
harus tidak \\
keterampilan & dalam \\
membakar & dan \\
membungkus. &
\end{tabular} & $\begin{array}{l}\text { CV Abdan } \\
\text { memberikan fee } \\
\text { pada hari tertentu } \\
\text { seperti hari raya } \\
\text { lebaran, dan } \\
\text { ketika penjualan } \\
\text { meningkat }\end{array}$ & $\begin{array}{l}\text { Karena kendaraan sangat } \\
\text { diperlukan untuk } \\
\text { mengantar pesanan dan } \\
\text { seragam diberikan } \\
\text { kepada semua karyawan }\end{array}$ \\
\hline Jumlah Pekerja & 0 & 15 orang & 15 orang & 15 orang \\
\hline Nama CV & \multicolumn{4}{|c|}{ Pemberian } \\
\hline $\begin{array}{l}\text { CV. Multi Agro } \\
\text { Guna }\end{array}$ & $\begin{array}{l}\text { Tunjangan } \\
\text { Kesehatan }\end{array}$ & $\begin{array}{l}\text { Pengembangan } \\
\text { SDM dan } \\
\text { Pendidikan } \\
\end{array}$ & Bonus & $\begin{array}{l}\text { Kendaraan dan } \\
\text { Seragam }\end{array}$ \\
\hline Keterangan & Iya & Tidak & Iya & Iya \\
\hline Alasan & $\begin{array}{lr}\text { Karena CV Multi Agro } \\
\text { Guna } & \text { memberikan } \\
\text { tunangan } & \text { kesehatan } \\
\text { kepada } & \text { karyawan } \\
\text { tetap. } & \end{array}$ & $\begin{array}{l}\text { CV. Multi Agro Guna } \\
\text { tidak memberikan } \\
\text { pengembangan SDM } \\
\text { dan pendidikan } \\
\text { kepada karyawan. }\end{array}$ & $\begin{array}{l}\text { CV. Multi Agro } \\
\text { Guna } \\
\text { memberikan fee } \\
\text { kepada karyawan } \\
\text { tetap minimal, } \\
\text { pemberian satu } \\
\text { tahun. }\end{array}$ & $\begin{array}{lr}\text { CV. Multi } & \text { Agro Guna } \\
\text { hanya } & \text { memberikan } \\
\text { seragam } & \text { kepada } \\
\text { karyawan tetap. }\end{array}$ \\
\hline Jumlah Pekerja & Hanya karyawan tetap & 0 & $\begin{array}{l}\text { Hanya karyawan } \\
\text { tetap }\end{array}$ & Hanya karyawan tetap. \\
\hline Nama CV & \multicolumn{4}{|c|}{$\begin{array}{c}\text { Pemberian } \\
\end{array}$} \\
\hline $\begin{array}{ll}\text { CV. } & \text { Rezky } \\
\text { Property } & \end{array}$ & $\begin{array}{l}\text { Tunjangan } \\
\text { Kesehatan }\end{array}$ & $\begin{array}{ll}\text { Pengembangan } & \\
\text { SDM dan } \\
\text { Pendidikan }\end{array}$ & Bonus & $\begin{array}{l}\text { Kendaraan } \\
\text { Seragam }\end{array}$ \\
\hline Keterangan & Iya & Iya & Iya & Iya \\
\hline Alasan & $\begin{array}{l}\text { CV. Rezky Property } \\
\text { memberikan tunjangan } \\
\text { kesehatan untuk } \\
\text { mensejahterakan } \\
\text { karyawan. }\end{array}$ & $\begin{array}{l}\text { CV. Rezky Property } \\
\text { memberikan } \\
\text { pengembangan SDM } \\
\text { dan Pendidikan untuk } \\
\text { meningkatkan skill } \\
\text { yang telah dimiliki } \\
\text { pada setiap karyawan. }\end{array}$ & $\begin{array}{l}\text { CV. Rezky } \\
\text { Property } \\
\text { memberikan } \\
\text { bonus untuk } \\
\text { menambah } \\
\text { semangat kerja } \\
\text { karyawan dan fee } \\
\text { dari kantor pusat. }\end{array}$ & $\begin{array}{l}\text { CV. Rezky Property } \\
\text { hanya memberikan } \\
\text { seragam kepada semua } \\
\text { karyawan yang dimiliki } \\
\text { dan tidak memberikan } \\
\text { kendaraan. }\end{array}$ \\
\hline Jumlah Pekerja & 4 orang & 4 orang & 4 orang & 4 orang \\
\hline Nama CV & \multicolumn{4}{|c|}{$\begin{array}{l}\text { Pemberian } \\
\end{array}$} \\
\hline $\begin{array}{l}\text { CV. Bengkulu } \\
\text { Mandiri }\end{array}$ & $\begin{array}{l}\text { Tunjangan } \\
\text { Kesehatan }\end{array}$ & $\begin{array}{ll}\text { Pengembangan } & \\
\text { SDM dan } \\
\text { Pendidikan }\end{array}$ & Bonus & $\begin{array}{l}\text { Kendaraan } \\
\text { Seragam }\end{array}$ \\
\hline Keterangan & Tidak & Tidak & Tidak & Kendaraan 1 \\
\hline Alasan & $\begin{array}{l}\text { CV. Bengkulu Mandiri } \\
\text { tidak memberikan }\end{array}$ & $\begin{array}{r}\text { Bengkulu } \\
\text { tidak } \\
\end{array}$ & $\begin{array}{lr}\text { CV. } & \text { Bengkulu } \\
\text { Mandiri } & \text { tidak } \\
\end{array}$ & $\begin{array}{l}\text { CV. Bengkulu Mandiri } \\
\text { hanya menyediakan } 1\end{array}$ \\
\hline
\end{tabular}




\begin{tabular}{|c|c|c|c|c|}
\hline & $\begin{array}{lr}\text { tunjangan } & \text { kesehatan } \\
\text { kepada } & \text { karyawan } \\
\text { karena dana yang } \\
\text { dimiliki kurang. }\end{array}$ & $\begin{array}{l}\text { memberikan } \\
\text { pengembangan SDM } \\
\text { dan pendidikan } \\
\text { kepada karyawan } \\
\text { karena sebelum } \\
\text { menjadi karyawan } \\
\text { harus memiliki skill } \\
\text { terlebih dahulu. }\end{array}$ & $\begin{array}{l}\text { memberikan } \\
\text { bonus kepada } \\
\text { karyawan karena } \\
\text { keterbatasan } \\
\text { dana. }\end{array}$ & $\begin{array}{l}\text { unit kendaraan dan tidak } \\
\text { menyediakan seragam } \\
\text { untuk karyawan. }\end{array}$ \\
\hline Jumlah Pekerja & 0 & 0 & 0 & 1 orang \\
\hline Nama CV & \multicolumn{4}{|c|}{ Pemberian } \\
\hline CV. Asoka Wisata & $\begin{array}{l}\text { Tunjangan } \\
\text { Kesehatan }\end{array}$ & $\begin{array}{l}\text { Pengembangan } \\
\text { SDM dan } \\
\text { Pendidikan }\end{array}$ & Bonus & $\begin{array}{l}\text { Kendaraan } \\
\text { Seragam }\end{array}$ \\
\hline Keterangan & Tidak & Iya & Tidak & Iya \\
\hline Alasan & $\begin{array}{lr}\text { CV. } & \text { Asoka Wisata } \\
\text { tidak } & \text { memberikan } \\
\text { tunjangan } & \text { kesehatan } \\
\text { kepada } & \text { karyawan } \\
\text { karena } & \text { keterbatasan } \\
\text { dana yang dimiliki. }\end{array}$ & $\begin{array}{l}\text { CV. Asoka Wisata } \\
\text { bergerak dalam } \\
\text { bidang jasa yaitu } \\
\text { travel. Untuk itu } \\
\text { pemberian pendidika } \\
\text { dilakukan dengan } \\
\text { memberikan pelatihan } \\
\text { mengendarai (driver) } \\
\text { yang baik dan benar } \\
\text { kapada karyawan. }\end{array}$ & $\begin{array}{lr}\text { CV. } & \text { Asoka } \\
\text { Wisata } & \text { tidak } \\
\text { memberikan } & \\
\text { bonus } & \text { kepada } \\
\text { karyawan } & \text { karena } \\
\text { belum } & \text { cukup } \\
\text { dana. } & \end{array}$ & $\begin{array}{lrr}\text { Untuk kendaran } & \text { dan } \\
\text { seragam kerja } & \text { CV. } \\
\text { Asoka Wisata } & \text { sudah } \\
\text { menyediakan. } & \end{array}$ \\
\hline Jumlah Pekerja & 0 & 8 orang & 0 & 8 orang \\
\hline Nama CV & \multicolumn{4}{|c|}{ Pemberian } \\
\hline $\begin{array}{ll}\text { CV. } & \text { Baruna } \\
\text { Indonesia } & \end{array}$ & $\begin{array}{l}\text { Tunjangan } \\
\text { Kesehatan }\end{array}$ & $\begin{array}{l}\text { Pengembangan } \\
\text { SDM dan } \\
\text { Pendidikan } \\
\end{array}$ & Bonus & $\begin{array}{l}\text { Kendaraan dan } \\
\text { Seragam }\end{array}$ \\
\hline Keterangan & Iya & Iya & Iya & Iya \\
\hline Alasan & $\begin{array}{lr}\text { CV. Baruna Indonesia } \\
\text { memberikan } & \text { tunjangan } \\
\text { kesehatan } & \text { kepada } \\
\text { karyawan } & \text { agar } \\
\text { kehidupan } & \text { karyawan } \\
\text { sejahtera. } & \end{array}$ & $\begin{array}{l}\text { Setiap karyawan harus } \\
\text { memiliki skill masing- } \\
\text { masing. }\end{array}$ & $\begin{array}{l}\mathrm{CV} \text { Baruna } \\
\text { Indonesia } \\
\text { memberikan } \\
\text { motivasi/fee agar } \\
\text { karyawan lebih } \\
\text { baik lagi dalam } \\
\text { bekerja. }\end{array}$ & $\begin{array}{l}\text { CV. Baruna } \text { Indonesia } \\
\text { menyediakan kendaran } \\
\text { untuk memperlancar } \\
\text { pekerjaan karyawan. }\end{array}$ \\
\hline Jumlah Pekerja & 4 orang & 4 orang & 4 orang & 1 orang. \\
\hline Nama CV & \multicolumn{4}{|c|}{$\begin{array}{r}\text { Pemberian } \\
\end{array}$} \\
\hline CV. Suka Sari & $\begin{array}{l}\text { Tunjangan } \\
\text { Kesehatan }\end{array}$ & $\begin{array}{ll}\text { Pengembangan } & \\
\text { SDM dan } \\
\text { Pendidikan }\end{array}$ & Bonus & $\begin{array}{l}\text { Kendaraan } \\
\text { Seragam }\end{array}$ \\
\hline Keterangan & Tidak & Iya & Tidak & $\begin{array}{ll}\text { Seragam tidak, } \\
\text { kendaraan iya. }\end{array}$ \\
\hline Alasan & $\begin{array}{lr}\mathrm{CV} \text { tidak } & \text { memberikan } \\
\text { tunjangan } & \text { kesehatan } \\
\text { karena } & \text { terhambat } \\
\text { modal yang dimiliki. }\end{array}$ & $\begin{array}{l}\text { CV. Suka Sari } \\
\text { memberikan } \\
\text { peningkatan } \\
\text { pengembangan skill } \\
\text { yang telah dimiliki } \\
\text { karyawan }\end{array}$ & $\begin{array}{l}\text { CV. Suka Sari } \\
\text { tidak } \\
\text { menyediakan } \\
\text { bonus karena } \\
\text { keterbatasan } \\
\text { modal yang } \\
\text { dimiliki. }\end{array}$ & $\begin{array}{l}\text { CV. Suka sari hanya } \\
\text { menyediakan kendaraan } \\
\text { agar mempermudah } \\
\text { pekerjaan karyawan. }\end{array}$ \\
\hline Jumlah Pekerja & 0 & 2 orang & 0 & 2 orang \\
\hline Nama CV & \multicolumn{4}{|c|}{$\begin{array}{r}\text { Pemberian } \\
\end{array}$} \\
\hline CV. Arau & $\begin{array}{l}\text { Tunjangan } \\
\text { Kesehatan }\end{array}$ & $\begin{array}{ll}\text { Pengembangan } & \\
\text { SDM dan } \\
\text { Pendidikan }\end{array}$ & Bonus & $\begin{array}{l}\text { Kendaraan } \\
\text { Seragam }\end{array}$ \\
\hline Keterangan & Tidak & Iya & Iya & Iya \\
\hline Alasan & $\begin{array}{l}\text { CV tidak menyediakan } \\
\text { tunjangan kesehatan } \\
\text { karena terhambat dana } \\
\text { yang dimiliki. }\end{array}$ & $\begin{array}{l}\text { CV memberikan } \\
\text { pengembangan SDM } \\
\text { untuk meningkatkan } \\
\text { keterlampilan yang } \\
\text { telah dimiliki } \\
\text { karyawan. }\end{array}$ & $\begin{array}{l}\text { CV memberikan } \\
\text { bonus agar } \\
\text { karyawan lebih } \\
\text { semangat lagi } \\
\text { dalam bekerja. }\end{array}$ & $\begin{array}{l}\text { Agar mengetahui } \\
\text { identitas dari CV. Arau. }\end{array}$ \\
\hline Jumlah Pekerja & 0 & 3 orang. & 3 orang & 3 orang \\
\hline Nama CV & \multicolumn{4}{|c|}{ Pemberian } \\
\hline
\end{tabular}




\begin{tabular}{|c|c|c|c|c|}
\hline CV. Elektro & $\begin{array}{l}\text { Tunjangan } \\
\text { Kesehatan }\end{array}$ & $\begin{array}{l}\text { Pengembangan } \\
\text { SDM dan } \\
\text { Pendidikan }\end{array}$ & Bonus & $\begin{array}{ll}\text { Kendaraan } & \text { dan } \\
\text { Seragam } & \end{array}$ \\
\hline Keterangan & Iya & Iya & Iya & Iya \\
\hline Alasan & $\begin{array}{l}\text { Untuk menjamin } \\
\text { kinerja karyawan. }\end{array}$ & $\begin{array}{l}\text { Iya karena karyawan } \\
\text { yang bekerja di cv } \\
\text { kami harus bisa dan } \\
\text { mempunyai } \\
\text { keterampilan di } \\
\text { bidang pekerjaan yang } \\
\text { sebagiab } \\
\text { karyawan besar } \\
\text { membenarkan atas } \\
\text { yang rusak. Jadi } \\
\text { tranning sangat } \\
\text { diperlukan di cv kami. }\end{array}$ & $\begin{array}{l}\text { Kalau karyawan } \\
\text { berprestasi diberi } \\
\text { bonus. }\end{array}$ & $\begin{array}{l}\text { Seragam untuk identitas, } \\
\text { sepatu untuk safty, dan } \\
\text { kendaraan untuk } \\
\text { operasional mengantar } \\
\text { barang dagang. }\end{array}$ \\
\hline Jumlah Pekerja & 20 orang & 10 orang. & 10 orang & 10 orang \\
\hline Nama CV & \multicolumn{4}{|c|}{ Pemberian } \\
\hline CV. Gunawan & $\begin{array}{l}\text { Tunjangan } \\
\text { Kesehatan }\end{array}$ & $\begin{array}{l}\text { Pengembangan } \\
\text { SDM dan } \\
\text { Pendidikan }\end{array}$ & Bonus & $\begin{array}{l}\text { Kendaraan } \\
\text { Seragam }\end{array}$ \\
\hline Keterangan & Iya & Iya & Iya & Iya \\
\hline Alasan & $\begin{array}{l}\text { Karena untuk } \\
\text { mensejahterakan } \\
\text { karyawan. }\end{array}$ & $\begin{array}{l}\text { Untuk mengikuti } \\
\text { perkembangan ilmu } \\
\text { dan IPTEK. }\end{array}$ & $\begin{array}{l}\text { Jika karyawan } \\
\text { lembur maka akan } \\
\text { diberi fee. }\end{array}$ & $\begin{array}{l}\text { Karena untuk menunjang } \\
\text { kerja karyawan dan } \\
\text { untuk operasional. }\end{array}$ \\
\hline Jumlah Pekerja & 4 orang & 4 orang. & 4 orang & 4 orang \\
\hline Nama CV & \multicolumn{4}{|c|}{ Pemberian } \\
\hline CV. PO BHI & $\begin{array}{l}\text { Tunjangan } \\
\text { Kesehatan }\end{array}$ & $\begin{array}{ll}\text { Pengembangan } & \\
\text { SDM dan } \\
\text { Pendidikan }\end{array}$ & Bonus & $\begin{array}{l}\text { Kendaraan } \\
\text { Seragam }\end{array}$ \\
\hline Keterangan & Iya & Iya & Tidak & Iya \\
\hline Alasan & $\begin{array}{l}\text { Untuk menjamin kerja } \\
\text { karyawan }\end{array}$ & $\begin{array}{lr}\text { Untuk meningkatkan } \\
\text { pengetahuan } & \text { yang } \\
\text { telah } & \text { dimiliki } \\
\text { karyawan } & \end{array}$ & $\begin{array}{l}\mathrm{Cv} \text { tidak } \\
\text { memberikan } \\
\text { bonus karena } \\
\text { keterbatasan } \\
\text { biaya. }\end{array}$ & $\begin{array}{l}\text { Untuk operasional dan } \\
\text { identitas cv. }\end{array}$ \\
\hline Jumlah Pekerja & 2 orang & 2 orang & 2 orang & 2 orang \\
\hline Nama CV & \multicolumn{4}{|c|}{ Pemberian } \\
\hline $\begin{array}{ll}\text { CV. } & \text { Mitra } \\
\text { Sejahtera } & \end{array}$ & $\begin{array}{l}\text { Tunjangan } \\
\text { Kesehatan }\end{array}$ & $\begin{array}{ll}\text { Pengembangan } & \\
\text { SDM dan } \\
\text { Pendidikan }\end{array}$ & Bonus & $\begin{array}{l}\text { Kendaraan } \\
\text { Seragam }\end{array}$ \\
\hline Keterangan & Tidak & Tidak & Iya & $\begin{array}{l}\text { Tidak ada seragam, } \\
\text { kendaraan Iya }\end{array}$ \\
\hline Alasan & $\begin{array}{ll}\mathrm{Cv} \text { tidak } & \text { menyediakan } \\
\text { tunjuangan } & \text { kesehatan } \\
\text { karena } & \text { minimnya } \\
\text { penghasilan dari cv. }\end{array}$ & $\begin{array}{l}\text { Karena sebelum } \\
\text { bergabung } \\
\text { keperusahaan } \\
\text { karyawan } \\
\text { memiliki skill. }\end{array}$ & $\begin{array}{l}\text { Karena jika } \\
\text { pendapatan } \\
\text { meningkat maka } \\
\text { karyawan akan } \\
\text { mendapatkan } \\
\text { bonus. }\end{array}$ & $\begin{array}{lr}\text { Kendaraan } & \text { sangat } \\
\text { diperlukan dalam } \mathrm{cv} \text { ini } \\
\text { untuk } \\
\text { penumpang. }\end{array}$ \\
\hline Jumlah Pekerja & 0 & 0 & 6 orang & 0 \\
\hline Nama CV & \multicolumn{4}{|c|}{ Pemberian } \\
\hline CV. Dimas Travel & $\begin{array}{l}\text { Tunjangan } \\
\text { Kesehatan }\end{array}$ & $\begin{array}{l}\text { Pengembangan } \\
\text { SDM dan } \\
\text { Pendidikan }\end{array}$ & Bonus & $\begin{array}{l}\text { Kendaraan } \\
\text { Seragam }\end{array}$ \\
\hline Keterangan & Tidak & Tidak & Iya & Tidak \\
\hline Alasan & $\begin{array}{l}\text { CV tidak menyediakan } \\
\text { tunjangan kesehatan } \\
\text { karena terhambat dana } \\
\text { yang dimiliki. }\end{array}$ & $\begin{array}{l}\text { Karena karyawan cv } \\
\text { ini rata-rata sudah } \\
\text { memiliki } \\
\text { keterampilan sebelum } \\
\text { bergabung didalam } \\
\text { cv. }\end{array}$ & $\begin{array}{l}\text { Bonus diberikan } \\
\text { tergantung } \\
\text { pendapatan yang } \\
\text { didapatkan } \\
\text { karyawan. }\end{array}$ & $\begin{array}{l}\text { Karena } \text { CV ini } \\
\text { menggunakan seragam } \\
\text { bebas selain karena } \\
\text { faktor modal, dana yang } \\
\text { dimiliki minim. }\end{array}$ \\
\hline Jumlah Pekerja & 0 & 7 orang & 7 orang & 0 \\
\hline Nama CV & \multicolumn{4}{|c|}{ Pemberian } \\
\hline
\end{tabular}




\begin{tabular}{|c|c|c|c|c|}
\hline $\begin{array}{l}\text { CV. Anggi Wisata } \\
\text { Travel }\end{array}$ & $\begin{array}{l}\text { Tunjangan } \\
\text { Kesehatan }\end{array}$ & $\begin{array}{l}\text { Pengembangan } \\
\text { SDM dan } \\
\text { Pendidikan }\end{array}$ & Bonus & $\begin{array}{l}\text { Kendaraan dan } \\
\text { Seragam }\end{array}$ \\
\hline Keterangan & Tidak & Iya & Iya & Iya \\
\hline Alasan & $\begin{array}{lr}\text { CV tidak menyediakan } \\
\text { tunjangan kesehatan } \\
\text { karena } \quad \text { minimnya } \\
\text { modal yang dimiliki } \\
\text { cv. }\end{array}$ & $\begin{array}{l}\text { Karena untuk } \\
\text { meningkatkan } \\
\text { pengetahuan dan } \\
\text { keahlian para pekerja } \\
\text { yang telah dimiliki. }\end{array}$ & $\begin{array}{l}\text { Karena untuk } \\
\text { meningkatkan } \\
\text { semangat } \\
\text { karyawan. }\end{array}$ & $\begin{array}{l}\mathrm{Cv} \text { menyediakan } \\
\text { seragam agar identitas cv } \\
\text { diketahui. }\end{array}$ \\
\hline Jumlah Pekerja & 0 & 5 orang. & 5 orang & 5 orang \\
\hline Nama CV & \multicolumn{4}{|c|}{ Pemberian } \\
\hline $\begin{array}{ll}\text { CV. } & \text { Life } \\
\text { Bersaudara } & \end{array}$ & $\begin{array}{l}\text { Tunjangan } \\
\text { Kesehatan }\end{array}$ & $\begin{array}{ll}\text { Pengembangan } & \\
\text { SDM dan } \\
\text { Pendidikan }\end{array}$ & Bonus & $\begin{array}{l}\text { Kendaraan dan } \\
\text { Seragam }\end{array}$ \\
\hline Keterangan & Tidak & Iya & Iya & Iya \\
\hline Alasan & $\begin{array}{l}\mathrm{Cv} \text { Life } \\
\text { tidak mersaudara } \\
\text { tunjangan kesehatan } \\
\text { karena minim modal } \\
\text { yang dimiliki cv. }\end{array}$ & $\begin{array}{lr}\text { Karena } & \text { sebelum } \\
\text { menjadi } & \text { karyawan } \\
\text { harus memiliki skill. }\end{array}$ & $\begin{array}{l}\text { CV memberikan } \\
\text { bonus agar } \\
\text { karyawan lebih } \\
\text { semangat dan giat } \\
\text { dalam bekerja. }\end{array}$ & $\begin{array}{lr}\text { Untuk mempermudah } \\
\text { melaksanakan pekerjaan } \\
\text { karena } \\
\text { diketahui. }\end{array}$ \\
\hline Jumlah Pekerja & 0 & 8 orang. & 8 orang & 8 orang \\
\hline Nama CV & \multicolumn{4}{|c|}{$\begin{array}{c}\text { Pemberian } \\
\end{array}$} \\
\hline $\begin{array}{l}\text { CV. } \\
\text { Travel }\end{array}$ & $\begin{array}{l}\text { Tunjangan } \\
\text { Kesehatan }\end{array}$ & \begin{tabular}{|l|} 
Pengembangan \\
SDM dan \\
Pendidikan
\end{tabular} & Bonus & $\begin{array}{ll}\text { Kendaraan } & \text { dan } \\
\text { Seragam } & \end{array}$ \\
\hline Keterangan & Tidak & Tidak & Tidak & Iya \\
\hline Alasan & $\begin{array}{l}\text { CV tidak menyediakan } \\
\text { tunjangan kesehatan } \\
\text { karena terhambat dana } \\
\text { yang dimiliki. }\end{array}$ & $\begin{array}{lr}\mathrm{CV} & \text { tidak } \\
\text { menyediakan } & \\
\text { pengembangan SDM } \\
\text { dan pendidikan karena } \\
\text { sebelum bergabung } \\
\text { karyawan harus } \\
\text { memiliki skill terlebih } \\
\text { dahulu. }\end{array}$ & $\begin{array}{lr}\mathrm{Cv} & \text { tidak } \\
\text { memberikan } & \\
\text { bonus } & \text { karena } \\
\text { dana } & \text { yang } \\
\text { dimiliki } & \mathrm{cv} \\
\text { minim. } & \end{array}$ & $\begin{array}{l}\text { Sebagai identitas dari } \\
\text { sebuah cv. }\end{array}$ \\
\hline Jumlah Pekerja & 0 & 0 & 0 & 8 orang \\
\hline Nama CV & \multicolumn{4}{|c|}{$\begin{array}{c}\text { Pemberian } \\
\end{array}$} \\
\hline CV. Planet ADV & $\begin{array}{l}\text { Tunjangan } \\
\text { Kesehatan }\end{array}$ & $\begin{array}{ll}\text { Pengembangan } \\
\text { SDM dan } \\
\text { Pendidikan }\end{array}$ & Bonus & $\begin{array}{l}\text { Kendaraan dan } \\
\text { Seragam }\end{array}$ \\
\hline Keterangan & Iya & Tidak & Iya & $\begin{array}{l}\text { Iya, hanya menyediakan } \\
\text { seragam. }\end{array}$ \\
\hline Alasan & $\begin{array}{lr}\text { Karena } & \text { program } \\
\text { kesehatan } & \text { sangat } \\
\text { penting } & \text { untuk } \\
\text { menunjang } & \text { kinerja } \\
\text { karyawan pada cv ini. }\end{array}$ & $\begin{array}{l}\text { Tidak, karena cv kami } \\
\text { menerima karyawan } \\
\text { yang sudah siap } \\
\text { bekerja dan dana } \\
\text { minim karena ini juga } \\
\text { membuang-buang } \\
\text { waktu. }\end{array}$ & $\begin{array}{ll}\text { Iya, karena jika } \\
\text { mendapatkan } \\
\text { borongan } \\
\text { adversiting yang } \\
\text { banyak san lama } \\
\text { bekerja yang } \\
\text { dilakukan } \\
\text { karyawan tentu } \\
\text { saja akan } \\
\text { mendapatkan } \\
\text { upah lembur yang } \\
\text { lebih. } \\
\end{array}$ & $\begin{array}{l}\text { Karena seragam sangat } \\
\text { penting } \\
\text { mengetahui identitas cv } \\
\text { kita, kalau untuk } \\
\text { operasional itu ada } \\
\text { beberapa yang dipakai } \\
\text { bersama. }\end{array}$ \\
\hline Jumlah Pekerja & 15 orang & 0 & 15 orang & 15 orang \\
\hline
\end{tabular}

\begin{tabular}{|c|c|c|c|c|}
\hline Nama CV & \multicolumn{4}{|c|}{$\begin{array}{r}\text { Pemberian } \\
\end{array}$} \\
\hline CV Unggul Karta & Tunjangan Kesehatan & $\begin{array}{l}\text { Pengembangan SDM } \\
\text { dan Pendidikan }\end{array}$ & Bonus & Kendaraan dan Seragam \\
\hline Keterangan & Tidak & Tidak & Tidak & $\begin{array}{l}\text { Kendaran tidak, Seragam } \\
\text { Tidak }\end{array}$ \\
\hline Alasan & $\begin{array}{l}\text { CV Belum mempunyai } \\
\text { cukup dana }\end{array}$ & $\begin{array}{lr}\text { Sebelum } & \text { menjadi } \\
\text { karyawan } & \text { mereka }\end{array}$ & $\begin{array}{l}\text { CV mempunyi } \\
\text { keterbatasan }\end{array}$ & $\begin{array}{l}\mathrm{CV} \text { belum mempunyai } \\
\text { cukup dana }\end{array}$ \\
\hline
\end{tabular}




\begin{tabular}{|c|c|c|c|c|}
\hline & & $\begin{array}{l}\text { harus mempunyai skill } \\
\text { terlebih dahulu }\end{array}$ & $\begin{array}{lr}\text { modal } & \text { dan } \\
\text { pendapatan } & \text { yang } \\
\text { kurang } & \\
\end{array}$ & \\
\hline Jumlah Pekerja & 0 & Semua Karyawan & Semua Karyawn & 0 \\
\hline Nama CV & \multicolumn{4}{|c|}{$\begin{array}{l}\text { Pemberian } \\
\end{array}$} \\
\hline CV Alex Grafika & Tunjangan Kesehatan & $\begin{array}{l}\text { Pengembangan SDM } \\
\text { dan Pendidikan }\end{array}$ & Bonus & Kendaraan dan Seragam \\
\hline Keterangan & Tidak & Iya & Iya & Iya \\
\hline Alasan & $\begin{array}{l}\text { CV belum mempunyai } \\
\text { cukup modal }\end{array}$ & $\begin{array}{lr}\mathrm{CV} & \text { meningkatkan } \\
\text { keterampilan karyawan }\end{array}$ & $\begin{array}{l}\text { CV memberikan } \\
\text { semangat kepada } \\
\text { karyaan agar giat } \\
\text { dalam bekerja }\end{array}$ & $\begin{array}{l}\text { Supaya karyawan } \\
\text { mengetahui identitas CV }\end{array}$ \\
\hline Jumlah Pekerja & 0 & Semua karyawan & $\begin{array}{ll}\text { Hampir } & \text { semua } \\
\text { karyawan, } \\
\text { tergantung } \\
\text { kenerja }\end{array}$ & Seluruh karyawan \\
\hline Nama CV & \multicolumn{4}{|c|}{ Pemberian } \\
\hline $\begin{array}{l}\text { CV Duta Enim } \\
\text { Wisata }\end{array}$ & Tunjangan Kesehatan & $\begin{array}{l}\text { Pengembangan SDM } \\
\text { dan Pendidikan }\end{array}$ & Bonus & Kendaraan dan Seragam \\
\hline Keterangan & Tidak & Tidak & Iya & Tidak \\
\hline Alasan & $\begin{array}{l}\text { CV hanya memberikan } \\
\text { tunjangan dan bonus } \\
\text { saja kepada kayawan }\end{array}$ & $\begin{array}{lr}\text { Karyawan } & \text { sudah } \\
\text { memiliki ketermpilan } \\
\text { dan skill }\end{array}$ & $\begin{array}{l}\text { CV memberikan } \\
\text { bonus kepada } \\
\text { karyawan } \\
\text { tergantung dari } \\
\text { banyaknya tarikan }\end{array}$ & $\begin{array}{l}\text { CV belum mempuyai } \\
\text { cukup modal dan dana }\end{array}$ \\
\hline Jumlah Pekerja & 0 & 5 orang & $\begin{array}{l}\text { Tergantung dari } \\
\text { banyaknya jam } \\
\text { lembur }\end{array}$ & 0 \\
\hline Nama CV & \multicolumn{4}{|c|}{ Pemberian } \\
\hline CV Bunga Mas & Tunjangan Kesehatan & $\begin{array}{l}\text { Pengembangan SDM } \\
\text { dan Pendidikan }\end{array}$ & Bonus & Kendaraan dan Seragam \\
\hline Keterangan & Tidak & Tidak & Iya & Tidak \\
\hline Alasan & $\begin{array}{l}\text { CV belum mempunyi } \\
\text { cukup modal }\end{array}$ & $\begin{array}{l}\text { Sebelum CV menerima } \\
\text { karyawan, mereka } \\
\text { sudah } \\
\text { keterampilannya }\end{array}$ & $\begin{array}{lr}\text { CV memberikan } \\
\text { bonus } & \text { kepada } \\
\text { karyawan } & \text { sesuai } \\
\text { dengan } & \text { kinerja } \\
\text { dan } & \text { jam } \\
\text { lemburnya } & \\
\end{array}$ & $\begin{array}{l}\text { CV belum mempunyai } \\
\text { cukup modal untuk } \\
\text { menyediakan kendaraan } \\
\text { dan seragam untuk } \\
\text { karyawan }\end{array}$ \\
\hline Jumlah Pekerja & 0 & 4 orang & $\begin{array}{l}\text { Hampir semua } \\
\text { karyawan }\end{array}$ & 0 \\
\hline Nama CV & \multicolumn{4}{|c|}{ Pemberian } \\
\hline CV Basuki Rahmat & Tunjangan Kesehatan & $\begin{array}{l}\text { Pengembangan SDM } \\
\text { dan Pendidikan }\end{array}$ & Bonus & Kendaraan dan Seragam \\
\hline Keterangan & Tidak & Tidak & Tidak & Tidak \\
\hline Alasan & $\begin{array}{l}\text { CV belum mempunyai } \\
\text { cukup dana dan modal } \\
\text { untuk memberikan } \\
\text { tunjangan } \\
\text { karyawan }\end{array}$ & $\begin{array}{l}\text { Karyawan } r \text { sudah } \\
\text { memiliki keterampilan } \\
\text { sendiri }\end{array}$ & $\begin{array}{lr}\text { Karyawan } & \mathrm{CV} \\
\text { tidak } & \text { pernah } \\
\text { lembur } & \end{array}$ & $\begin{array}{l}\text { CV belum mempunyai } \\
\text { cukup dana }\end{array}$ \\
\hline Jumlah Pekerja & 0 & 5 orang & 0 & 0 \\
\hline Nama CV & \multicolumn{4}{|c|}{ Pemberian } \\
\hline CV Abadi & Tunjangan Kesehatan & $\begin{array}{l}\text { Pengembangan SDM } \\
\text { dan Pendidikan }\end{array}$ & Bonus & Kendaraan dan Seragam \\
\hline Keterangan & Tidak & Tidak & Iya & Tidak \\
\hline Alasan & $\begin{array}{lr}\mathrm{CV} & \text { mempunyai } \\
\text { masalah } & \text { keterbatasan } \\
\text { dana } & \\
\end{array}$ & $\begin{array}{l}\text { Karyawan sudah } \\
\text { mempunyai } \\
\text { keterampilan yang baik } \\
\end{array}$ & $\begin{array}{l}\text { Supaya karyawan } \\
\text { semangat bekerja }\end{array}$ & $\begin{array}{l}\text { CV memiliki masalah } \\
\text { keterbatasan dana }\end{array}$ \\
\hline Jumlah Pekerja & 0 & Seluruh karyawan & Seluruh karyawan & 0 \\
\hline Nama CV & \multicolumn{4}{|c|}{ Pemberian } \\
\hline CV Linggau Travel & Tunjangan Kesehatan & $\begin{array}{l}\text { Pengembangan SDM } \\
\text { dan Pendidikan }\end{array}$ & Bonus & Kendaraan dan Seragam \\
\hline Keterangan & Iya & Tidak & Iya & Iya \\
\hline Alasan & $\begin{array}{lr}\mathrm{CV} & \text { memyediakan } \\
\text { asuransi } & \text { untuk } \\
\text { karyawan } & \end{array}$ & \begin{tabular}{lr}
\multicolumn{2}{l}{ Sebelum CV menerima } \\
karyawan mereka \\
sudah & diuji \\
keterampilan & dan \\
kemampuannya & \\
\end{tabular} & $\begin{array}{lr}\mathrm{CV} & \text { menghargai } \\
\text { kerja } & \text { keras } \\
\text { karyawannya }\end{array}$ & 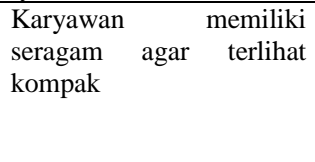 \\
\hline
\end{tabular}




\begin{tabular}{|c|c|c|c|c|}
\hline Jumlah Pekerja & Semua karyawan & 0 & Semua karyawan & Semua karyawan \\
\hline Nama CV & \multicolumn{4}{|c|}{$\begin{array}{l}\text { Pemberian } \\
\end{array}$} \\
\hline $\begin{array}{l}\text { CV Nira Kurnia } \\
\text { Sakti }\end{array}$ & Tunjangan Kesehatan & $\begin{array}{l}\text { Pengembangan SDM } \\
\text { dan Pendidikan }\end{array}$ & Bonus & Kendaraan dan Seragam \\
\hline Keterangan & Tidak & Tidak & Tidak & Tidak \\
\hline Alasan & $\begin{array}{l}\text { CV belum mempunyai } \\
\text { dana }\end{array}$ & $\begin{array}{l}\text { CV hanya melihat } \\
\text { kinerja karyawan pada } \\
\text { saat bekerja }\end{array}$ & $\begin{array}{l}\text { Karena } \\
\text { keterbatasan dana }\end{array}$ & $\begin{array}{lll}\begin{array}{l}\text { Pendapatan } \\
\text { terbatas }\end{array} & & \text { yang } \\
\end{array}$ \\
\hline Jumlah Pekerja & 0 & o & 0 & 0 \\
\hline Nama CV & \multicolumn{4}{|c|}{ Pemberian } \\
\hline CV Columbia & Tunjangan Kesehatan & $\begin{array}{l}\text { Pengembangan SDM } \\
\text { dan Pendidikan }\end{array}$ & Bonus & Kendaraan dan Seragam \\
\hline Keterangan & Tidak & Iya & Iya & Iya \\
\hline Alasan & $\begin{array}{l}\text { Karena } \\
\text { modal }\end{array}$ & $\begin{array}{lr}\text { Adanya } & \text { pelatihan } \\
\text { karyawan dalam } & \text { dan } \\
\text { mengelolah } & \text { kredit }\end{array}$ & $\begin{array}{l}\text { Apabila karyawan } \\
\text { melebihi target } \\
\text { penjualan }\end{array}$ & $\begin{array}{l}\text { Baju seragam sebagai } \\
\text { identitas } \mathrm{CV}\end{array}$ \\
\hline Jumlah Pekerja & 0 & & Semua karyawan & Semua karyawan \\
\hline Nama CV & \multicolumn{4}{|c|}{$\begin{array}{c}\text { Pemberian } \\
\end{array}$} \\
\hline $\begin{array}{l}\text { CV PO Sriwijaya } \\
\text { Express }\end{array}$ & Tunjangan Kesehatan & $\begin{array}{l}\text { Pengembangan SDM } \\
\text { dan Pendidikan }\end{array}$ & Bonus & Kendaraan dan Seragam \\
\hline Keterangan & Iya & Tidak & Iya & Tidak \\
\hline Alasan & $\begin{array}{lr}\text { Karena tunjangan } \\
\text { sangat diperlukan } \\
\text { karyawan } \mathrm{CV}\end{array}$ & $\begin{array}{lr}\text { Karyawan } & \text { sudah } \\
\text { memiliki } & \text { keterapilan } \\
\text { dalam pekerjaan nya }\end{array}$ & $\begin{array}{lr}\text { Agar } & \text { karyawan } \\
\text { semangat dalam } \\
\text { bekerja dan Bonus } \\
\text { yang diberikan } \\
\text { sesuai dengan } \\
\text { jarak yang di } \\
\text { tempuh }\end{array}$ & Keterbatasan modal \\
\hline Jumlah Pekerja & 5 orang & 0 & Semua karyawan & 0 \\
\hline Nama CV & \multicolumn{4}{|c|}{$\begin{array}{l}\text { Pemberian } \\
\end{array}$} \\
\hline CV Armada Travel & Tunjangan Kesehatan & $\begin{array}{l}\text { Pengembangan SDM } \\
\text { dan Pendidikan }\end{array}$ & Bonus & Kendaraan dan Seragam \\
\hline Keterangan & $\begin{array}{l}\text { Iya, CV memberikan } \\
\text { asuransi Jasa Raharja }\end{array}$ & Iya & Tidak & Iya, seragam \\
\hline Alasan & $\begin{array}{l}\text { Sebagai tanggung } \\
\text { jawab dari CV }\end{array}$ & $\begin{array}{l}\text { Supaya mengetahui } \\
\text { kemampuan dan skill } \\
\text { karyawan }\end{array}$ & $\begin{array}{l}\text { Semua kayawan } \\
\text { bekerja hanya } \\
\text { pada waktu kerja } \\
\text { tanpa ada lembur } \\
\text { dan lain-lain }\end{array}$ & $\begin{array}{l}\text { Agara karyawan terlihat } \\
\text { kompak }\end{array}$ \\
\hline Jumlah Pekerja & Semua karyawan & Semua karyawan & 0 & Semua karyawan \\
\hline Nama CV & \multicolumn{4}{|c|}{$\begin{array}{r}\text { Pemberian } \\
\end{array}$} \\
\hline CV Pesisir Indah & Tunjangan Kesehatan & $\begin{array}{l}\text { Pengembangan SDM } \\
\text { dan Pendidikan }\end{array}$ & Bonus & Kendaraan dan Seragam \\
\hline Keterangan & Tidak & Tidak & Tidak & Tidak \\
\hline Alasan & Keterbatasan modal & $\begin{array}{l}\text { Karyawan sudah } \\
\text { mempunyai skill dan } \\
\text { keterampilan }\end{array}$ & $\begin{array}{l}\text { Keterbatasan } \\
\text { modal }\end{array}$ & Keterbatasan modal \\
\hline Jumlah Pekerja & 0 & 0 & 0 & 0 \\
\hline
\end{tabular}

\begin{tabular}{|c|c|c|c|c|}
\hline Nama CV & \multicolumn{4}{|c|}{$\begin{array}{l}\text { Pemberian } \\
\end{array}$} \\
\hline CV Modhelom & Tunjangan Kesehatan & $\begin{array}{l}\text { Pengembangan SDM } \\
\text { dan Pendidikan }\end{array}$ & Bonus & $\begin{array}{l}\text { Kendaraan } \\
\text { Seragam }\end{array}$ \\
\hline Keterangan & Tidak & Tidak & Iya & Iya \\
\hline Alasan & $\begin{array}{l}\text { CV belum mempunyai } \\
\text { cuku modal }\end{array}$ & $\begin{array}{l}\text { Karena sebelum } \\
\text { diterima bekerja di CV } \\
\text { karyawan sudah dilihat } \\
\text { keterampilannya }\end{array}$ & $\begin{array}{l}\text { Supaya karyawan } \\
\text { semngat dalam } \\
\text { bekerja }\end{array}$ & $\begin{array}{l}\text { Supaya pelangan } \\
\text { mengenali karyawan CV } \\
\text { (sebagai tanda pengenal) }\end{array}$ \\
\hline Jumlah Pekerja & 0 & 0 & Semua karyawan & Semua karyawan \\
\hline Nama CV & \multicolumn{4}{|c|}{ Pemberian } \\
\hline CV Bintar Utara & Tunjangan Kesehatan & $\begin{array}{l}\text { Pengembangan SDM } \\
\text { dan Pendidikan }\end{array}$ & Bonus & $\begin{array}{l}\text { Kendaraan } \\
\text { Seragam }\end{array}$ \\
\hline Keterangan & Iya, Jasa Raharja & Iya & Tidak & Iya,seragam \\
\hline Alasan & $\begin{array}{l}\text { Karena sebagai } \\
\text { tanggung jawab CV } \\
\text { terhadap karyawan }\end{array}$ & $\begin{array}{l}\text { Untuk melatih } \\
\text { keterampilan dan skill } \\
\text { karyawan }\end{array}$ & $\begin{array}{l}\text { Karyawan bekerja } \\
\text { pada saat jam } \\
\text { kerja saja }\end{array}$ & $\begin{array}{l}\text { Sebagi tanda pengenal } \\
\text { karyawan }\end{array}$ \\
\hline Jumlah Pekerja & 10 orang & 10 orang & 0 & 10 orang \\
\hline
\end{tabular}




\begin{tabular}{|c|c|c|c|c|}
\hline Nama CV & \multicolumn{4}{|c|}{ Pemberian } \\
\hline CV Talang Tegar & Tunjangan Kesehatan & $\begin{array}{l}\text { Pengembangan SDM } \\
\text { dan Pendidikan }\end{array}$ & Bonus & $\begin{array}{l}\text { Kendaraan } \\
\text { Seragam }\end{array}$ \\
\hline Keterangan & Iya & Tidak & Iya & Tidak \\
\hline Alasan & $\begin{array}{lr}\text { CV } & \text { memberikan } \\
\text { kenyamanan } & \text { dalam } \\
\text { bekerja } & \text { kepada } \\
\text { karyawan } & \end{array}$ & $\begin{array}{lr}\text { Sebelum } & \text { menjadi } \\
\text { karyawan, } & \text { mereka } \\
\text { sudah } & \text { dilihat } \\
\text { pendidikan dan } & \text { diuji } \\
\text { keterampilannya }\end{array}$ & $\begin{array}{l}\text { Agar karyawan } \\
\text { semangat dalam } \\
\text { bekerja }\end{array}$ & $\begin{array}{l}\mathrm{CV} \text { mempunyai masalah } \\
\text { keterbatasan dana }\end{array}$ \\
\hline Jumlah Pekerja & Semua karyawan & 0 & Semua karyawan & 0 \\
\hline Nama CV & \multicolumn{4}{|c|}{ Pemberian } \\
\hline CV Lestari Com & Tunjangan Kesehatan & $\begin{array}{l}\text { Pengembangan SDM } \\
\text { dan Pendidikan }\end{array}$ & Bonus & $\begin{array}{l}\text { Kendaraan dan } \\
\text { Seragam }\end{array}$ \\
\hline Keterangan & Tidak & Tidak & Iya & $\begin{array}{l}\text { Kendaraan Iya } \\
\text { Seragam Tidak }\end{array}$ \\
\hline Alasan & $\begin{array}{lr}\mathrm{CV} & \text { mempunyai } \\
\text { masalah } & \text { keterbatasan } \\
\text { dana } & \end{array}$ & $\begin{array}{lr}\text { Karyawan } & \text { sudah } \\
\text { mempunyai } & \\
\text { keterampilan } & \text { dan } \\
\text { kinerja yang baik } & \end{array}$ & $\begin{array}{l}\text { Sesuai dengan jam } \\
\text { lembur yang } \\
\text { dilakukan } \\
\text { karyawan }\end{array}$ & $\begin{array}{l}\text { Kendaraan memudahkan } \\
\text { karyawan dalam } \\
\text { pengantaran barang } \\
\text { kepada konsumen } \\
\text { Sedangan alas an tidak } \\
\text { adanya seragam karena } \\
\text { keterbatasan dana }\end{array}$ \\
\hline Jumlah Pekerja & 0 & 0 & Semua karyawan & Semua karyawan \\
\hline Nama CV & \multicolumn{4}{|c|}{ Pemberian } \\
\hline CV Indah Cargo & Tunjangan Kesehatan & $\begin{array}{l}\text { Pengembangan SDM } \\
\text { dan Pendidikan }\end{array}$ & Bonus & $\begin{array}{l}\text { Kendaraan } \\
\text { Seragam }\end{array}$ \\
\hline Keterangan & Iya & Tidak & Tidak & $\begin{array}{l}\text { Kendaraan tidak } \\
\text { Seragam tidak }\end{array}$ \\
\hline Alasan & $\begin{array}{lr}\text { Untuk } & \text { memberikan } \\
\text { keamanan } & \text { dan } \\
\text { kenyaman } & \text { karyawan } \\
\text { dalam bekerja } & \end{array}$ & $\begin{array}{lr}\text { Karyawan } & \text { sudah } \\
\text { memiliki } & \text { terampil } \\
\text { dalam } & \text { pengembangan } \\
\text { diri } & \end{array}$ & $\begin{array}{l}\mathrm{CV} \text { mempunyai } \\
\text { keterbatasan dana }\end{array}$ & $\begin{array}{l}\mathrm{CV} \text { mempunyai } \\
\text { keterbatasan dana }\end{array}$ \\
\hline Jumlah Pekerja & Semua karyawan & 0 & 0 & 0 \\
\hline Nama CV & \multicolumn{4}{|c|}{$\begin{array}{ll}\text { Pemberian } \\
\end{array}$} \\
\hline CV Sumber Pandai & Tunjangan Kesehatan & $\begin{array}{l}\text { Pengembangan SDM } \\
\text { dan Pendidikan }\end{array}$ & Bonus & $\begin{array}{l}\text { Kendaraan } \\
\text { Seragam }\end{array}$ \\
\hline Keterangan & Tidak & Tidak & Iya & Tidak \\
\hline Alasan & $\begin{array}{lr}\mathrm{CV} & \text { mempunyai } \\
\text { masalah } & \text { keterbatasan } \\
\text { dana } & \end{array}$ & $\begin{array}{lr}\text { CV sudah } & \text { memiliki } \\
\text { karyawan } & \text { yang } \\
\text { terampil } & \end{array}$ & $\begin{array}{l}\text { Memberikan } \\
\text { bonus tau fee } \\
\text { untuk karyawan } \\
\text { yang lembur }\end{array}$ & $\begin{array}{l}\text { CV mempunyai masalah } \\
\text { keterbatasaan dana }\end{array}$ \\
\hline Jumlah Pekerja & 0 & 0 & Seluruh karyawan & 0 \\
\hline Nama CV & \multicolumn{4}{|c|}{ Pemberian } \\
\hline $\begin{array}{l}\text { CV Media } \\
\text { Bengkulu Jaya }\end{array}$ & Tunjangan Kesehatan & $\begin{array}{l}\text { Pengembangan SDM } \\
\text { dan Pendidikan }\end{array}$ & Bonus & $\begin{array}{l}\text { Kendaraan } \\
\text { Seragam }\end{array}$ \\
\hline Keterangan & Tidak & Tidak & Iya & Tidak \\
\hline Alasan & $\begin{array}{l}\text { Karena keterbatasannya } \\
\text { dana }\end{array}$ & $\begin{array}{l}\text { CV sudah mempunyai } \\
\text { karyawan yang trampil } \\
\text { dalam melakukan } \\
\text { pengembangan diri }\end{array}$ & $\begin{array}{lr}\text { CV memberikan } \\
\text { bonus } & \text { kepda } \\
\text { karyawan } & \text { yang } \\
\text { lembur } & \end{array}$ & $\begin{array}{l}\mathrm{CV} \text { mempunyai masalah } \\
\text { keterbatasan modal }\end{array}$ \\
\hline Jumlah Pekerja & 0 & 0 & Seluruh karyawan & 0 \\
\hline Nama CV & \multicolumn{4}{|c|}{ Pemberian } \\
\hline CV Raja Pesona & Tunjangan Kesehatan & $\begin{array}{l}\text { Pengembangan SDM } \\
\text { dan Pendidikan }\end{array}$ & Bonus & $\begin{array}{l}\text { Kendaraan } \\
\text { Seragam }\end{array}$ \\
\hline Keterangan & Tidak & Iya & Tidak & Iya, seragam \\
\hline Alasan & $\begin{array}{l}\mathrm{CV} \text { mempunyai } \\
\text { keterbatasan modal }\end{array}$ & $\begin{array}{l}\text { Untuk menggetahui } \\
\text { skill setiap karyawan }\end{array}$ & $\begin{array}{l}\text { Karyawan bekerja } \\
\text { pada waktu jam } \\
\text { kerja tanpa adanya } \\
\text { lembur }\end{array}$ & $\begin{array}{l}\text { Sebagai tanda pengenal } \\
\text { karyawan CV Raja } \\
\text { Pesona }\end{array}$ \\
\hline Jumlah Pekerja & 0 & 3orang & 0 & 3 orang \\
\hline
\end{tabular}

Sumber : Peneliti, 2018

Pembahasan

Tax Planning atas PPH Badan
1. Tax Planning atas PPH Badan Perusahaan Komanditer (CV) di Kota Bengkulu 
Skema perencanaan pajak (Tax Planning) :

Bagian kasus ini peneliti dan tim tidak mendapatkan data laporan tentang pajak dan data laporan keuangan (Neraca dan Laba rugi) secara menyeluruh, hanya beberapa yang peneliti dapatkan, maka pendekatan dalam menyelesaikan skema ini, peneliti menggunakan data dari hasil wawancara dan data pajak dan data laporan keuangan (Neraca dan Laba rugi) yang diberikan.

\section{a. Menganalisis Informasi yang ada}

Dalam hal ini mayoritas CV kurang melakukannya atau dapat dikatakan CV awam dalam menerima info info tentang PPH badan, Pemilik Usaha Berbentuk CV bahkan cenderung tidak melakukannya karena keterbatasan informasi dan dana mereka, mereka cenderung tidak mengetahui apabila terdapat sosialisasi tentang PPH badan dikarenakan Pemilik Usaha Berbentuk $\mathrm{CV}$ kurang proaktif dalam hal ini, Informasi yang ada hanya menjadi ketakutan Pemilik Usaha Berbentuk CV akan pembayaran PPH badan, ketakutan ini menjadi bumerang sehingga mereka mengambil jalan pintas, yakni mereka menemui petugas pajak dan kemudian mereka meminta bantuan dalam menyelesaikan laporan PPH badannya sehingga dengan membuat laporan PPH badannya, maka akan diketahui berapa besaran PPH badan yang wajib dibayar.

b. Membuat suatu model atau lebih rencana kemungkinan besarnya pajak Model atau rencana kemungkinan besaran pajak akan didapatkan oleh Pemilik Usaha Berbentuk CV apabila Pemilik Usaha Berbentuk CV telah mendapatkan informasi yang jelas dan akurat, maka Pemilik Usaha Berbentuk CV akan dapat membuat prediksi ini, namun yang terjadi Pemilik Usaha Berbentuk CV tidak memperhatikan akan hal ini, sehingga mereka tidak dapat membuat suatu rencana yang lebih baik dalam pembayaran PPH badanya.

c. Mengevaluasi pelaksanaan rencana pajak

Ketergantungan Pemilik Usaha Berbentuk CV dengan pihak lembaga pajak dalam pembuatan laporan PPH badan menjadi hal yang negatif untuk Pemilik Usaha Berbentuk CV itu sendiri, hal apa yang didapatkan adalah Pemilik
Usaha Berbentuk CV tidak dapat melakukan sebuah evaluasi rencana pajak, Pemilik Usaha Berbentuk CV hanya menjadikan aktivitas tahunan ini tidak lebih hanya jadi sebuah aktivitas saja, bukan sebuah aktivitas pembelajaran.

d. Mencari kelemahan dan kemudian memperbaiki kembali rencana pajak

Dengan penjelasan beberapa point diatas, maka Pemilik Usaha Berbentuk CV akan sangat kesulitan mencari kelemahan dan apalagi memperbaiki kembali rencana pajaknya, yang peneliti dan tim lakukan, dikarenakan Pemilik Usaha Berbentuk CV tidak memiliki milestone yang jelas tentang riwayat perpajakan $\mathrm{CV}$ mereka

e. Memutakhiran rencana pajak

Hal ini menjadi masalah buat Pemilik Usaha Berbentuk CV, ketergantungan mereka membuat laporan PPH badan dengan pihak lembaga pajak menjadi kebiasan yang buruk, sehingga dalam melakukan mutakhir rencana pajak, maka Pemilik Usaha Berbentuk CV tidak dapat berbuat banyak.

2. Tax Planning atas PPH Badan Perusahaan Komanditer (CV) di Kota Lubuklinggau

Skema perencanaan pajak (Tax Planning) :

Dalam kasus ini peneliti dan tim tidak mendapatkan data laporan tentang pajak dan data laporan keuangan (Neraca dan Laba rugi) secara menyeluruh, maka pendekatan dalam menyelesaikan skema ini, peneliti menggunakan data dari hasil wawancara yang diberikan.

a. Menganalisis Informasi yang ada

Dalam hal ini mayoritas CV kurang melakukannya atau dapat dikatakan CV awam dalam menerima info info tentang PPH badan, Pemilik Usaha Berbentuk CV bahkan cenderung tidak melakukannya karena keterbatasan informasi dan dana mereka, mereka cenderung tidak mengetahui apabila terdapat sosialisasi tentang PPH badan dikarenakan Pemilik Usaha Berbentuk CV kurang proaktif dalam hal ini, Informasi yang ada hanya menjadi momok (ketakutan) Pemilik Usaha Berbentuk CV akan pembayaran PPH badan, ketakutan ini menjadi 
bumerang sehingga mereka mengambil jalan pintas, yakni mereka menemui petugas pajak dan kemudian mereka meminta bantuan dalam menyelesaikan laporan PPH badannya sehingga dengan membuat laporan PPH badannya, maka akan diketahui berapa besaran PPH badan yang wajib dibayar.

b. Membuat suatu model atau lebih rencana kemungkinan besarnya pajak Model atau rencana kemungkinan besaran pajak akan didapatkan oleh Pemilik Usaha Berbentuk CV apabila Pemilik Usaha Berbentuk CV telah mendapatkan informasi yang jelas dan akurat, maka Pemilik Usaha Berbentuk CV akan dapat membuat prediksi ini, namun yang terjadi Pemilik Usaha Berbentuk CV tidak memperhatikan akan hal ini, sehingga mereka tidak dapat membuat suatu rencana yang lebih baik dalam pembayaran $\mathrm{PPH}$ badanya.

c. Mengevaluasi pelaksanaan rencana pajak

Ketergantungan Pemilik Usaha Berbentuk CV dengan pihak lembaga pajak dalam pembuatan laporan PPH badan menjadi hal yang negatif untuk Pemilik Usaha Berbentuk CV itu sendiri, hal apa yang didapatkan adalah Pemilik Usaha Berbentuk CV tidak dapat melakukan sebuah evaluasi rencana pajak, Pemilik Usaha Berbentuk CV hanya menjadikan aktivitas tahunan ini tidak lebih hanya jadi sebuah aktivitas saja, bukan sebuah aktivitas pembelajaran.

d. Mencari kelemahan dan kemudian memperbaiki kembali rencana pajak Dengan penjelasan beberapa point diatas, maka Pemilik Usaha Berbentuk CV akan sangat kesulitan mencari kelemahan dan apalagi memperbaiki kembali rencana pajaknya, yang peneliti dan tim lakukan, dikarenakan Pemilik Usaha Berbentuk CV tidak memiliki milestone yang jelas tentang riwayat perpajakan $\mathrm{CV}$ mereka

e. Memutakhirkan rencana pajak

Hal ini menjadi masalah buat Pemilik Usaha Berbentuk CV, ketergantungan mereka membuat laporan PPH badan dengan pihak lembaga pajak menjadi kebiasan yang buruk, sehingga dalam melakukan mutakhir rencana pajak, maka Pemilik Usaha Berbentuk CV tidak dapat berbuat banyak.
Efisiensi Pengelolaan Keuangan Dalam Membayar PPH Badan Melalui Kegiatan Tax Planning

Dengan mempertimbangkan tindakantindakan yang sebaiknya diambil dalam mengefisiensikan Pajak Penghasilan Badan terutang tahun 2015 berdasarkan UndangUndang No. 36 tahun 2008 pasal 9 ayat (1) dan Undang-Undang No. 36 tahun 2006 pasal 9 ayat (1) huruf e, maka dapat dilakukan kegiatan - kegiatan sebagai berikut :

1. Pemberian tunjangan kesehatan untuk karyawan

2. Pemberian pengembangan SDM dan pendidikan bagi karyawan.

3. Pemberian bonus atas prestasi kerja karyawan.

4. Pemberian kendaraan untuk alat transportasi

5. Pemberian seragam untuk karyawan.

\section{Efisiensi PPH Badan CV Wilayah Kota}

Lubuklinggau

Pemberian Tunjangan Kesehatan

Dari semua objek, mayoritas memberikan tunjangan kesehatan kepada karyawannya, ada beberapa perusahaan yang memberikan tunjangan kesehatan hanya untuk karyawan tetapnya saja, tetapi ada juga yang memberikan kepada karyawan tidak tetap, tunjangan kesehatan yang diberikan berupa BPJS Kesehatan, BPJS Ketenargakerjaan (opsional), dan Bantuan langsung dari CV kepada karyawannya. CV yang tidak memberikan tunjangan kesehatan mempunyai alasan yang hampir sama, yakni mereka menempatkan karyawan sebagai karyawan tidak tetap atau kontrak.

Pemberian pengembangan SDM dan pendidikan bagi karyawan

Ada dua temuan yang berbeda dengan variasi yang hampir sama, sisi kelompok pertama, CV memberikan bantuan pengembangan SDM dan pendidikan bagi karyawannya dikarenakan CV tersebut memang harus melakukan hal tersebut karena sudah tuntutan perkembangan teknologi, namum sisi kelompok kedua, CV tidak melakukan aktivitas pengembangan SDM dan pendidikan bagi karyawan dikarenakan $\mathrm{CV}$ kelompok ini sudah melakukan rekrutmen dengan hanya menerima Karyawan yang ahli di bidangnya. 
Pemberian bonus atas prestasi kerja karyawan

Pemberian bonus atas prestasi kerja karyawan telah dilakukanoleh sebagaian besar objek, mereka memberikan bonus dapat berupa THR (Tunjangan Hari Raya) dan bonus berupa capaian apabila memenuhi target atau melampaui target penjualan / produksi / dan sejenisnya yang telah ditentukan oleh $\mathrm{CV}$, terdapat juga $\mathrm{CV}$ yang memberikan sebuah penghargaan kepada Karyawannya berupa pemberian bonus uang dan travelling.

Pemberian kendaraan untuk alat transportasi, dan Pemberian seragam untuk karyawan

Pemberian kendaraan dilakukan oleh objek (CV) hanya kepada Karyawan yang memang membutuhkannya sebagai bagian dari Job Description nya, seperti Mobil (untuk CV yabg bergerak di travel, motor untuk delivery, dan jenis kendaraan lainnya yang disesuaikan dengan posisinya didalam CV). Pemberian seragam tidak banyak dilakukan oleh $\mathrm{CV}$, hanya beberapa yang melakukan fungsi ini dikarenakan mereka mempunyai keterbatasan biaya operasionalnya, namum ada juga CV (beberapa) yang memberikan seragam kepada karyawannya sebagai bentuk apresiasi, bentuk keseragaman, bentuk kekompakkan, dan bentuk ciri khas mereka.

Efisiensi PPH Badan CV Wilayah Kota Bengkulu

Pemberian Tunjangan Kesehatan

Dari semua objek, mayoritas tidak memberikan tunjangan kesehatan kepada karyawannya, ada beberapa perusahaan yang memberikan tunjangan kesehatan hanya untuk karyawan tetapnya saja, tetapi ada juga yang memberikan kepada karyawan tidak tetap, tunjangan kesehatan yang diberikan berupa BPJS Kesehatan, BPJS Ketenargakerjaan (opsional), dan Bantuan langsung dari CV kepada karyawannya. CV yang tidak memberikan tunjangan kesehatan mempunyai alasan secara keseluruhan yang hampir sama, yakni mereka mengalami keterbatasan dana dalam membayar tunjangan kesehatan ini.

Pemberian pengembangan SDM dan pendidikan bagi karyawan

Ada dua temuan yang berbeda dengan variasi yang hampir sama, namun mayoritas temuan adalah Pemilik Usaha Berbentuk CV tidak melakukan hal ini, sisi kelompok pertama, Pemilik Usaha Berbentuk CV memberikan bantuan pengembangan SDM dan pendidikan bagi karyawannya dikarenakan $\mathrm{CV}$ tersebut memang harus melakukan hal tersebut karena sudah tuntutan perkembangan teknologi, namum sisi kelompok kedua, CV tidak melakukan aktivitas pengembangan SDM dan pendidikan bagi karyawan dikarenakan CV kelompok ini sudah melakukan rekrutmen dengan hanya menerima Karyawan yang ahli di bidangnya dan karena keterbatasan dana yang didalam CV mereka.

Pemberian bonus atas prestasi kerja karyawan

Pemberian bonus atas prestasi kerja karyawan telah dilakukanoleh sebagaian besar objek (Pemilik Usaha Berbentuk CV) dan mayoritas telah dilakukan oleh Pemilik Usaha Berbentuk CV, mereka memberikan bonus dapat berupa THR (Tunjangan Hari Raya) dan bonus berupa capaian apabila memenuhi target atau melampaui target penjualan / produksi / dan sejenisnya yang telah ditentukan oleh $\mathrm{CV}$, terdapat juga $\mathrm{CV}$ yang memberikan sebuah penghargaan kepada Karyawannya berupa pemberian bonus uang lembur.

Pemberian kendaraan untuk alat transportasi, dan Pemberian seragam untuk karyawan

Pemberian kendaraan dilakukan oleh objek (CV) hanya kepada Karyawan yang memang membutuhkannya sebagai bagian dari Job Description nya, seperti Mobil (untuk CV yabg bergerak di travel, motor untuk delivery, dan jenis kendaraan lainnya yang disesuaikan dengan posisinya didalam CV). Pemberian seragam tidak banyak dilakukan oleh $\mathrm{CV}$, hanya beberapa yang melakukan fungsi ini dikarenakan mereka mempunyai keterbatasan biaya operasionalnya, namum ada juga CV (beberapa) yang memberikan seragam kepada karyawannya sebagai bentuk apresiasi, bentuk keseragaman, bentuk kekompakkan, dan bentuk ciri khas mereka. Mayoritas item ini tidak dilakukan oleh Pemilik Usaha Berbentuk CV karena dana mereka yang minim

\section{Kesimpulan}

1. Tax Planning atas PPH Badan sesuai dengan Peraturan Perpajakan mayoritas dari Pemilik Usaha Berbentuk CV masih belum diterapkan secara optimal. 
2. Dalam pengelolaan keuangan Pemilik Usaha Berbentuk CV baik di Kota Lubuklinggau dan Kota Bengkulu belum dapat mengefisiensikan pembayaran $\mathrm{PPH}$ Badannya.

\section{Saran}

1. Sebaiknya dalam melakukan Tax planning atas PPH Badan yang sesuai dengan Peraturan Perpajakan dilakukan secara langsung oleh pimpinan Pemilik Usaha Berbentuk CV.

2. Dalam pengelolaan keuangan, Pemilik Usaha Berbentuk CV di Kota Lubuklinggau dan Kota Bengkulu sebaiknya melakukan efisiensi pembayaran PPH badannya, dengan menggunakan mitra namun kemudian mempelajarinya dan akhirnya dapat melakukannya secara mandiri untuk kedepannya.

3. Untuk riset selanjutnya sebaiknya memperluas area objek dan menambah Instrumen lainnya.

\section{Daftar Pustaka}

Arikunto Suhermi. 2010. Prosedur Penelitian Suatu Pendekatan Praktik. Cetakan ke 14. Jakarta : Rineka Cipta.

Helisnawati Dessy dan Yola Fahmi Ahmad. 2013. Analisis Perencanaan Pajak (Tax Planning) dalam upaya meningkatkan efisiensi beban pajak penghasilan badan pada PT. Akasha Internasional Tbk. Jurnal Ilmiah Manajemen dan Akuntansi. Fakultas Ekonomi (JIMAFE) Volume 12013.

Indah Yulia Puspitasari. 2011. Penerapan Tax Planning Atas Pajak Penghasilan (Pph) Badan (Studi Kasus Pada Cv. Scronica Sari). Jurnal Ilmiah Manajemen dan Akuntansi.

Mardiasmo. 2011. Perpajakan. Cetakan ke 17. Yogyakarta. Andi Offset

Muljono Djoko. 2009. Tax Planning menyiasati pajak dengan bijak. Cetakan ke 1. Yogyakarta: CV. Andi Offset.

Silitonga Laurens. 2013. Penerapan Tax Planning Atas Pajak Penghasilan Badan Pada CV. Andi Offset Cabang Manado. Jurnal EMBA. Vol. 1 No. 3 Hal. 829-839
Siregar Syofian. 2012. Statistik Parametik Untuk Penelitian Kuantitatif. Cetakan ke I. Jakarta : Remaja Rosdakarya.

Suandy Erly. 2008. Perencanaan Pajak. cetakan ke 4. Yogyakarta: Salemba Empat.

Sugiyono. 2013. Metode Penelitian Bisnis Pendekatan Kuantitatif, Kualitatif Dan $R \& D$. Cetakan ke 17. Bandung : Alfabeta.

Sunyoto Danang. 2013. Metode Penelitian Akuntansi. Cetakan ke 1. Yogyakarta : PT. Refika Aditama.

Susunan Dalam Satu Naskah UndangUndang Perpajakan No.7 Tahun 1983 Tentang Pajak Penghasilan Sebagaimana Telah Beberapa Kali Diubah Dengan Undang-Undang No.36 Tahun 2008. 2012. Jakarta: Kementerian Keuangan Republik Indonesia Direktorat Jenderal Pajak. 